\title{
DO IMPÉRIO DAS “REVOLUÇÕES” AO IMPÉRIO DA “ESCRAVIDÃO”: TEMAS, ARGUMENTOS E INTERPRETAÇÕES DA HISTÓRIA DO IMPÉRIO (1822-1950)*
}

\author{
From the empire of "revolutions" to the empire of \\ "slavery": arguments, subjects and interpretations of \\ the Brazilian Empire history (1822-1950)
}

Izabel Andrade Marson**

\begin{abstract}
RESUMO
$\mathrm{O}$ artigo historia os significados atribuídos ao período imperial nos séculos XIX e XX, destacando o percurso das motivações, argumentos e temas (a Revolução Liberal e a escravidão) que inspiraram seus principais intérpretes: Joaquim Nabuco, Oliveira Lima, Gilberto Freyre, Sérgio Buarque de Holanda, Caio Prado Jr. e Nelson Werneck Sodré. Dessa forma, acompanha leituras da época da monarquia que expressam diversos posicionamentos sobre o regime, as revoluções e as singularidades da nação brasileira. Na sequência, sinaliza análises construídas no período da república liberal (1889-1930) - de Oliveira Lima, Oliveira Vianna e Vicente Licínio Cardoso -, quando aconteceu um "debate convergente" que associou teses díspares da experiência monárquica. Por fim, aborda os "intérpretes modernos" do Brasil - Freyre, Holanda, Prado Jr e Sodré -, autores que (re)conceituaram, a partir de diferentes concepções sobre a Revolução Brasileira, o patrimônio argumentativo sobre a história do Brasil monárquico legado por seus antecessores.
\end{abstract}

Palavras-chave: historiografia; império; revolução; escravidão.

\footnotetext{
"Pesquisa financiada pelo CNPq.

"** Departamento de História - IFCH-UNICAMP.
} 


\begin{abstract}
This article describes the meanings given to the imperial period in the centuries XIX and XX. It highlights the pathway of motivations, arguments and subjects (The Liberal Revolution and slavery) which inspired their major interpreters: Joaquim Nabuco, Oliveira Lima, Gilberto Freyre, Sérgio Buarque de Holanda, Caio Prado Júnior and Nelson Werneck Sodré. Therefore, this article follows the readings of the monarchy times, which express several positions regarding the regime, revolutions, and singularities of the Brazilian nation. Next, it signals the analysis built in the liberal republic period (1889-1930) - from Oliveira Lima, Oliveira Vianna and Vicente Licínio Cardoso - when a "convergent debate" took place, which associated different thesis regarding the monarchic experience. Finally, the article deals with the "modern interpreters" of Brazil - Freyre, Holanda, Prado Junior and Sodré - authors who, from different conceptions on the Brazilian Revolution, (re)conceptualized the argumentative patrimony on the monarchic Brazil history, handed down by their antecessors.
\end{abstract}

Key-words: historiography; empire; revolution; slavery.

Desde as últimas décadas do século XIX, e com objetivos diversos, historiadores e estudiosos da história da literatura apreciaram obras que abordaram o Império Brasileiro. Nesse sentido, Sílvio Romero, Capistrano de Abreu e Pedro Moacyr Campos ${ }^{1}$ apontaram o perfil dos textos - se constituíam documentos, crônicas, criações literárias ou interpretações condizentes com parâmetros de uma "história-ciência" - e avaliaram eventuais vínculos com um efetivo projeto nacional - afinado com orientações "modernas" e universalizantes (liberais ou positivistas) -, ou com tradições reiterativas da história factual e laudatória das origens portuguesas. Desdobrando essas preocupações, a partir da década de 1950, Antonio Cândido, José Honório Rodrigues, Francisco Iglesias, Emília Viotti da Costa e Carlos Guilherme Mota esclareceram a "ideologia" imbricada nas obras, ou seja, seu comprometimento com ideais monárquicos ou republicanos, "progressistas" ou "reacionários"2.

1 ROMERO, Sylvio. História da literatura brasileira. Rio de Janeiro: Garnier, 1888. 2 v.; ABREU, João Capistrano de. Ensaios e estudos: crítica e história. São Paulo: Sociedade Capistrano de Abreu, 1931; CAMPOS, Pedro Moacyr. Esboço da historiografia brasileira nos séculos XIX e XX. In: GLÉNISSON, Jean. Iniciação aos estudos históricos. São Paulo: Difel, 1961, p. 250-293.

2 CÂNDIDO, Antonio. Formação da literatura brasileira (momentos decisivos). 3. ed. São Paulo: Martins Fontes, 1969. 2 v.; RODRIGUES, José Honório. Teoria da História do Brasil (Introdução 
Visando contribuir com o estudo de um tema já bastante visitado, procuramos historiar sentidos atribuídos ao período imperial nos séculos XIX e XX, bem como as problemáticas históricas que os inspiraram. Também identificamos matrizes e argumentos muito significativos para intérpretes clássicos - Joaquim Nabuco, Oliveira Lima, Gilberto Freyre, Sérgio Buarque de Holanda, Caio Prado Jr. e Nelson Werneck Sodré 3 . Assim, iniciamos com leituras criadas na época da monarquia e primeiros anos da república nas quais emergem percepções positivas e negativas do regime, diferentes opiniões sobre as revoluções e sobre as singularidades da nação, contrapostas ora à experiência europeia, ora à americana, ora a ambas. Tratava-se naquele momento de decidir sobre a monarquia ou a república, ou ainda, sobre o melhor perfil para a monarquia.

Na sequência, tangenciamos análises produzidas durante a república liberal (1900-1930), referências importantes para os estudiosos a partir de então. Comprometidas com o reconhecimento da "identidade nacional" e com a construção de uma história filosófica e científica fundada na erudição e no evolucionismo, nelas percebe-se um debate convergente que associou concepções díspares do período monárquico - aproximaram a tese da especificidade americana do país (cara aos republicanos e outros liberais críticos da monarquia), com a opinião positiva sobre as instituições monárquicas, típica dos adeptos incondicionais do regime. Ou seja, bem conduzidas pelo Imperador e seus estadistas, elas haviam sido importantes na configuração do território e da nacionalidade e na condução a bom termo de uma sociedade original, mas com virtudes e problemas herdados da colonização, proposições apresentadas com nuances por Oliveira Lima, Oliveira Vianna e Vicente Licínio Cardoso.

Por fim, num terceiro momento, abordamos os "intérpretes modernos" do Brasil - Freyre, Holanda, Prado Jr. e Sodré - autores motivados pelo tema da Revolução Brasileira entendida como superação das sequelas da

metodológica). 5. ed. atualizada. São Paulo: Ed. Nacional; Brasília: INL, 1978; IGLÉSIAS, Francisco. Historiadores do Brasil. Capítulos de historiografia brasileira. Rio de Janeiro: Nova Fronteira; B. Horizonte: Ed. UFMG, 2000; COSTA, Emília Viotti da. "Sobre as origens da República". In: Da monarquia à república: momentos decisivos. 2. ed. São Paulo: Ciências Humanas, 1979, p. 243-251; MOTA, Carlos Guilherme. Ideologia da cultura brasileira (1933-1964). Pontos de partida para uma revisão histórica. São Paulo: Ática, 1977. Ver também: MARTINS, Wilson. História da inteligência brasileira. São Paulo: Cultrix: Edusp, 1977-78. v. IV-VI.

3 Obviamente, o intuito não é esgotar todos os significados do período imperial, a historiografia que o abordou, ou a argumentação dos intérpretes aqui tratados. 
colonização e do período monárquico - em especial o latifúndio, a servidão e a escravidão. Verificamos como, a partir de referenciais teóricos liberais e marxistas, (re)conceituaram o patrimônio de argumentos e interpretações do século XIX e início do XX - por um lado reiteraram, de diferentes formas, a tese da originalidade da nação frente à experiência europeia $\mathrm{e}$ americana, mas, por outro, (re)avaliaram negativamente o Império, visto como momento de continuidade/declínio/evolução/desequilíbrio de uma suposta herança colonial. Nessas duas últimas circunstâncias, tratava-se de recolher os ensinamentos que a experiência monárquica poderia oferecer à República.

$\mathrm{Na}$ análise dessas obras foi possível perceber a importância de categorias específicas do ideário liberal - as revoluções liberais e o argumento "antigo regime, feudalismo, latifúndio, servidão escravidão" - reiteradamente utilizadas para explicar positiva ou negativamente a implantação, características e percurso do Império luso-brasileiro desde o final do XVIII até o $\mathrm{XX}^{4}$. A mais evidente razão dessa recorrência foi sua eficácia na explicação da singularidade da nação brasileira - a dificuldade em transitar da "barbárie à civilização"; em compor um conjunto organicamente estruturado e em contornar revoluções indesejáveis - pois nela preservavam-se práticas remanescentes da colonização, verdadeiros suportes do "despotismo", ou "independência", de sua elite política e da "servidão" dos homens livres sem propriedade: o monopólio da terra - prática assemelhada ao "feudalismo" europeu; e do trabalho, referido à "escravidão" africana ou indígena ${ }^{5}$. Vejamos as diferentes leituras desse argumento, das revoluções e da monarquia nas interpretações construídas sobre o Império ao longo do séculos XIX e XX (até os anos 50).

4 A exemplo de KOSTER, Henry. Viagens ao nordeste do Brasil. (Travels in Brazil). 2. ed. Trad. e Prefácio de Luiz da Câmara Cascudo. Recife: Secretaria da Educação e Cultura, 1942; TOLLENARE, Louis François. Notas dominicais tomadas durante a viagem em Portugal e no Brasil em 18l6, 1817 e 1818. Trad. de Alfredo de Carvalho. Prefácio de Manuel de Oliveira Lima. Revista do Instituto Archeológico e Geographico Pernambucano. Recife, v. XI-XII, n. 61 e 62, 1904-1905; VILHENA, Luís dos Santos. Noticias soteropolitanas. Notas de Braz do Amaral. 2. ed. Bahia; Imprensa Oficial, 1922. 2 v.; LISBOA, José da Silva. Memória dos beneficios do governo del Rei D. João VI. 2. ed. Rio de Janeiro: Imprensa Nacional, 1940; SAINT-HILAIRE, Auguste. Viagem à província de S. Paulo. São Paulo: Edusp; Martins Fontes, 1972; Segunda viagem do Rio de Janeiro a Minas Gerais e S. Paulo. B. Horizonte: Itatiaia; São Paulo: Edusp, 1974.

5 Os traços do "feudalismo" são o oposto daqueles da civilização: desconhecimento dos hábitos disciplinadores do corpo e da mente; o abuso e desrespeito em relação ao outro. ELIAS, Norbert. O processo civilizador. Uma história dos costumes. Trad. Ruy Jungmann. Revisão e apresentação de Renato Janine Ribeiro. Rio de Janeiro: Jorge Zahar, v. 1, p. 63, 1994; BLOCH, Marc. La societé féodale. Paris: Ed.Albin Michel, 1940; Les Rois Thaumaturges. Paris: Éd. Gallimard, 1983. 


\section{Um império de revoluções}

Conflitos de diversa natureza integraram a história do Brasil Império. Nos recintos parlamentares enfrentaram-se, no primeiro reinado, "portugueses e brasileiros"; na regência, "restauradores e liberais, exaltados e moderados"; e no segundo reinado, liberais e conservadores ocuparam a cena política até 1870 , quando a emergência oficializada dos republicanos veio adensar o confronto partidário e contribuir para a queda da monarquia em 1889. Contudo, fora do Parlamento, a agitação se evidenciou com mais nuances e complexidade, denotando a presença de uma sociedade intrincada em sua configuração e interesses ${ }^{6}$. Tal quadro de conflitos foi, certamente, um forte motivo para que o tema da Revolução se tornasse a principal referência do debate político e historiográfico desde 1822 até 1850 , debate revigorado na década de 1870 com a emergência dos "novos liberais" - e seu projeto de reforma da monarquia - e da proposta republicana.

O multifacetamento das revoluções liberais no final do século XVIII e início do XIX foi demonstrado por Hannah Arendt em estudo comparativo do movimento da Independência americana e da Revolução Francesa. A riqueza de argumentos e a complexidade das concepções de revolução apontadas por ela também podem ser reconhecidas no Brasil ao longo de todo Império, presentes em diferentes registros, desde obras que sistematizaram as primeiras histórias da nação, legitimadoras de um dado projeto nacional, como em opúsculos críticos da monarquia e de suas instituições escritos para a disputa político-partidária ${ }^{7}$.

A primeira análise da fundação do Império apareceu na História dos principais sucessos políticos do Império do Brasil ${ }^{8}$ (1827-30), de José

6 Lembramos: os confrontos com portugueses ("mata-marinheiro"); as insubordinações da tropa de linha; participações de militares em fatos significativos como a abdicação de D. Pedro I e a proclamação da República; levantes de diferentes orientações políticas: a Confederação do Equador, a Farroupilha, a Sabinada, a Revolução de 1842 em S. Paulo e Minas e a Praieira; as insurreições populares: a revolta dos Malês, as Cabanadas do Pará e de Alagoas, a Balaiada, o Ronco da Abelha o Quebra-Quilos.

7 Cf. MARSON, Izabel A. Hannah Arendt e a revolução: ressonâncias da revolução americana no império brasileiro. In: DUARTE, André; LOPREATO, Christina; MAGALHÃES, Marion B. (Orgs). $A$ banalização da violência: a atualidade do pensamento de Hannah Arendt. Rio de Janeiro:Relume Dumará, 2004. p. 227-246.

8 LISBOA, José da Silva (Visconde de Cairu). História dos principais sucessos políticos do Império do Brasil dedicada ao Senhor D. Pedro I. Rio de Janeiro: Typ. Imperial e Nacional, 1827/1830. 
da Silva Lisboa, onde a independência aparece como uma revolução "incruenta", uma "transição negociada" habilmente pelos príncipes da casa de Bragança desde sua chegada ao Brasil e, também, um episódio representativo da evolução da história do império lusitano, conforme bem apontou Cecília de Salles Oliveira:

\begin{abstract}
Obliterando nuanças, fragmentos, conflitos [...] Silva Lisboa projetou uma síntese coerente e "fidedigna" na qual [acontece] o aprisionamento do processo político à imagem incruenta de uma transição continuísta; [...] Uma das questões centrais proposta por sua obra reside na maneira pela qual reconhece diferentes interlocutores nas lutas políticas em curso - a "cabala antibrasílica" nas Cortes, os "anarquistas", os "republicanos" - mas retira deles a iniciativa das ações colocando-a, inicialmente, no âmbito restrito da pessoa do rei e depois nas mãos do Príncipe. Ao subtrair o espaço de atuação da sociedade, dos grupos políticos e de seus inúmeros porta-vozes, faz crer que a cronologia dos acontecimentos seja ditada pela sucessão linear de decisões adotadas pelas autoridades como se, no Brasil, a "revolução da Independência", como ele mesmo designou, fosse obra e graça do Estado monárquico, enraizado desde 1808, mas cujas tradições e legitimidade remontavam aos primórdios da monarquia portuguesa'.
\end{abstract}

Porém, a abdicação de Pedro I em 1831 e suas decorrências ensejaram outros entendimentos da criação e percurso da monarquia em seus primeiros anos. A História do Brasil, de John Armitage $(1835)^{10}$, destacou

Acervo da Biblioteca Nacional do Rio de Janeiro. O relato, devidamente documentado por decretos e deliberações de governo e outros documentos, apresenta os eventos de fevereiro de 1821 a março de 1823 (desde a movimentação popular ocorrida quando do juramento à futura Constituição feita pelas Cortes em Lisboa até o início do governo de D. Pedro I). OLIVEIRA, Cecília H. de Salles. Repercussões da revolução: delineamento do Império do Brasil, 1808/1831. In: GRINBERG, Keila; SALLES, Ricardo. Brasil Império. Rio de Janeiro: Civilização Brasileira, 2008. v. 1 (no prelo).

9 Ibid., p. 9-11.

10 ARMITAGE, John. História do Brasil desde o período da chegada da família de Bragança, em 1808, até a abdicação de D. Pedro I, em 1831, compilada à vista de documentos públicos e outras fontes originais formando uma continuação da História do Brasil de Southey. 2. ed. B. Horizonte: Itatiaia; São Paulo: Edusp, 1981. O autor era um comerciante inglês assíduo frequentador do paço durante o primeiro reinado; o texto foi publicado em Londres em 1836, e traduzido no Brasil em 1837. A obra de Southey (SOUTHEY, Robert. History of Brazil. Londres, 1819. 3 v.) tratou da história da colônia portuguesa até a instalação da 
os embates dos grupos atuantes na política entre 1808 e 1831 (realistas, liberais moderados e exaltados); a importância de vários personagens (Pedro I, Evaristo da Veiga, o senador Vergueiro, José Bonifácio, Feijó, Bernardo de Vasconcelos, Borges da Fonseca, dentre outros); e interpretou a "revolução da independência", e a de 1831, como "o progresso gradual de um povo desde a barbárie até uma relativa civilização", porque delas resultara o fim do "sistema colonial e do regime absoluto" $"$. Considera que a "barbárie" que singularizara a ex-colônia fora decorrência do "despotismo" da corte portuguesa e dos Capitães-Generais; da privação da comunicação e do comércio com outras nações e desconhecimento da educação e cultura existentes fora da metrópole; e da escravidão ${ }^{12}$. Sem ignorar a experiência positiva da monarquia constitucional e insistir no papel de D. Pedro I na construção do Império, valorizou a "prudência" da atuação dos liberais brasileiros na abdicação e a inevitabilidade e pertinência daquela revolução, pois decorria da peculiar configuração social e eleitoral do Brasil onde "a quase totalidade da população livre goza do privilégio de votar". Foi justamente essa dessemelhança entre a situação do Brasil e da Europa, em destaque a inexistência de uma aristocracia enraizada ${ }^{13}$, ou seja, do feudalismo, que o Imperador não soubera apreender. Ao se espelhar em outros soberanos (marcadamente os Bourbons), apesar de não ser um tirano, Pedro I não conseguira tornar-se "um homem do seu povo", embora contribuísse significativamente para impedir uma anarquia, "ainda mais fatal do que a que tem assolado as outras colônias espanholas", desfecho inevitável numa sociedade despreparada para a república ${ }^{14}$.

Corte no Brasil. Armitage faz uma rápida retomada da situação colonial e dos acontecimentos do século XVIII para, em seguida, relatar detalhadamente o período joanino e, especialmente, a independência e o primeiro reinado.

11 MARSON, Izabel A. O Império da Revolução: matrizes interpretativas dos conflitos na sociedade monárquica. In: FREITAS, Marcos Cezar (Org.). Historiografia brasileira em perspectiva. São Paulo: Contexto, 1998, p. 73-102. Armitage também foi estudado por: OLIVEIRA, Cecília H. L. de Salles - A astúcia liberal: relações de mercado no Rio de Janeiro (1820-1824). Bragança Paulista: EDUSF; Ícone, 1999. p. 20-28; sobre sua importância para os historiadores estrangeiros que abordaram a independência KRAAY, Hendrik. A visão estrangeira: a Independência do Brasil (1780-1850) na historiografia européia e norte-americana. In: JANCSÓ, István (Org.). Independência: História e Historiografia. São Paulo: Hucitec; Fapesp, 2005. p. 119-178.

12 ARMITAGE, J. História do Brasil. Op.cit. p. 30-31, 232.

13 Ibid., p. 174.

14 Ibid., p. 212-213; 226-227. 
Por sua vez, em $O$ Libelo do Povo (1849), o deputado liberal Torres Homem, o Timandro, também projetaria uma concepção positiva da revolução ${ }^{15}$. Dessa forma, reconstituiu a história do país de 1822 a 1848 para justificar os direitos históricos conferidos pela lei do progresso às revoltas liberais, em especial à Revolta de Pernambuco (1848), interpretada como "uma fase nova da mesma crise, que há vinte e cinco anos começou, enlutando as últimas cenas de nossa incompleta independência" ${ }^{16}, \mathrm{Ou}$, uma tentativa mal-sucedida de desmascaramento da monarquia constitucional aqui praticada - desfigurada pela ação recorrente do Poder Moderador -, que se apresentava ora numa "comédia de mau gosto", quando este poder interferia nos Ministérios e no desempenho da Câmara, ora em "drama sanguinolento", quando os cidadãos, reagindo às interferências inconstitucionais dos Príncipes da Casa de Bragança, recorriam às armas e eram violentamente reprimidos ${ }^{17}$. Destacou, também, seu parentesco com as revoltas europeias, aquelas que em 1848 impuseram constituições aos Bourbons e aos Habsburgos ${ }^{18}$, tornando-a um sucedâneo nacional da luta entre "a liberdade e a tirania", característica política essencial do século XIX. Para Timandro, a América em geral e o Brasil em particular estavam próximos das conquistas desse século, uma vez que aqui a realeza e o feudalismo não tinham raízes históricas.

Historiou o embate entre "o espírito nacional e o interesse recolonizador" dos Braganças. Assinalou o primeiro marco dessa luta na "revolução da independência", ocasião de um "novo pacto" entre a nação e a monarquia, regime de livre escolha dos cidadãos, pois "esse rei era simples feitura de nossas mãos"19. Este pacto fora desrespeitado pela primeira vez em 1824, quando o Príncipe, associado com uma "facção antinacional", confiscou os poderes da nação fechando a Assembléia Constituinte, outorgando a Constituição e reprimindo a Confederação do Equador. Diante de tal ataque, "a consciência pública ofendida jurou vingança", concretizada no 7 de abril com a abdicação ${ }^{20}$. A partir dela (entre 1831 a 1837), assistiu-se ao governo

15 HOMEM, Francisco Sales Torres. O Libelo do Povo. In: MAGALHÃES JR. Três panfletários do segundo reinado. São Paulo: Nacional, 1956. p. 47-126.

16 Ibid., p. 61.

17 Ibid., p. 108-111.

18 Ibid., p. 60.

19 Ibid., p. 62.

20 Ibid., p. 67, 74-75. 
da revolução, que saneou as finanças do país e instaurou a "verdadeira democracia" - dispensou o cerimonial, a etiqueta e os títulos de nobreza ${ }^{21}$ -, e reprimiu a "desordem" salvando o país da anarquia. Contudo, seu feito mais significativo foi o Ato Adicional de 1834, que instaurou o princípio da eleição dos regentes e delegou às províncias o direito de intervir na escolha de seus administradores, estabelecendo o "regime federativo, seiva animadora da civilização".

A queda de Feijó em 1837 teria assinalado um segundo rompimento do acordo constituído na independência, pois a regência de Araújo Lima iniciou a desconstrução da obra revolucionária 22 . A "facção recolonizadora", aliada ao Poder Moderador, dominaria a cena política interferindo, inconstitucionalmente, na formação dos ministérios e nas dissoluções da Câmara. A revolta tornar-se-ia o único meio possível para denunciar o desvirtuamento da monarquia constitucional e completar a "revolução da independência" 23 .

Para Timandro, a revolução liberal era, então, um compromisso histórico inadiável da "flor da sociedade brasileira" com o progresso, uma vez que, se direcionada pela "escória da população", ela se metamorfosearia de ordem e regularidade (conforme sugerido na natureza) em "desordem e anarquia". Assim, apoiou a opinião de Armitage sobre a revolução de 1831, mas, embora também admitisse os problemas herdados da colonização portuguesa e recusasse a existência do feudalismo e de uma nobreza enraizada, não admitiu os direitos da dinastia dos Braganças sobre o Império, nem o concebeu como defasado frente às nações europeias. Do ponto de vista político, apesar da escravidão, o Brasil e a América estavam plenamente afinados com as expectativas do século XIX.

Já o folheto Ação, reação, transação (1855) - do deputado conservador Justiniano José da Rocha - condenou enfaticamente as revoluções girondinas ou jacobinas ${ }^{24}$. Pretendendo superar outras leituras do percurso do Império e de suas instituições - em especial a de Timandro -, interpretou a história da nação à luz da "ciência da natureza" para tornar suas

21 Ibid., p. 76-80.

22 Ibid., p. 87-90.

23 Ibid., p.109, 126.

24 ROCHA, Justiniano José da. Ação, reação, transação: duas palavras acerca da atualidade. In: MAGALHÃES JR. Op.cit. p. 218. Rocha também era jornalista, professor de História do Colégio Pedro II e membro do IHGB. 
origens e desenvolvimento transparentes e previsíveis. Então, ordenou os acontecimentos em três períodos necessários - um de predomínio da "ação" (1822-1836), outro da "reação" (1837-1852), e um terceiro da "transação" (1852-1856) - e os submeteu a duas leis: a de "ação-reação, com etapas cíclicas sucessivas e inevitáveis resultantes do confronto instintivo e "eterno entre a liberdade e a autoridade"; e a "lei do progresso", que imprimiu a esse ritmo algum avanço quando a regularidade da ação-reação "fosse substituída pela moderação e racionalidade da transação" ${ }^{25}$.

Tendo por referência a situação europeia e discordando de Armitage e Timandro, Justiniano interpretou a atuação dos liberais na independência e na abdicação como "inexperiência" típica da infância das nações. Assim, entre 1822 e 1836, assistira-se ao domínio da "ação democrática", quando os "instintos e aspirações republicanas" foram acolhidos pelas "camadas superiores da inteligência brasileira", em virtude da "educação clássica e a juvenil admiração dos heróis de Roma e da Grécia; da reação contra o sofrimento e a iniquidade do absolutismo; e do prestigioso encantamento com a prosperidade dos Estados Unidos", referências inspiradoras de várias decisões arrebatadas: da Independência, da convocação da Constituinte e da revolta de Pernambuco em $1824^{26}$. O "poder", entretanto, contornou esse despreparo reagindo ponderada e habilmente pela mão do Imperador, salvando o Império da desagregação em 1823, dissolvendo a Constituinte em 1824, outorgando uma Constituição afinada com as mais avançadas proposições liberais e com o progresso; e em 1831, abdicando e evitando uma guerra civil e o "precipício da sua dinastia, e da monarquia brasileira" 27.

A "infalível" revolução do 7 de abril assinalou o "triunfo da ação democrática" que perduraria até 1836 e levaria a nação ao caos. Justiniano lamentou essa "falta de prudência" dos condutores da revolução em seus primeiros anos. mas, também, elogiou seu "instinto" patriótico que logrou reprimir a desordem ${ }^{28}$. Contudo, em 1837, chegou o tempo da reação: era

25 Subdividiu os períodos em cinco fases: ação: luta (1822-1831), ação: triunfo (1831-1836), luta da reação (1836-1840), triunfo monárquico (1840-1852) e transação (1852-1856). Uma crítica dessa leitura do percurso do Império foi feita por MATTOS, Ilmar Rohloff. O tempo saquarema. A formação do estado imperial. 2. ed. São Paulo: Hucitec, 1990. Cap. II (Luzias e Saquaremas: liberdades e hierarquias), p. $109-129$.

26 ROCHA, Justiniano José da. Op. cit., p.166.

27 Ibid., p. 176.

28 Ibid., p. 176-182. 
o começo do "regresso" que promulgaria a lei de interpretação do Ato Adicional, suporte maior daquela desordem ${ }^{29}$. A reação monárquica, iniciada com a regência de Araújo Lima, não significou um retorno ao passado, nem foi tão-somente realização de uma "facção recolonizadora", como queriam os liberais e referendara Timandro. Pelo contrário, foi sinal do esgotamento de uma fase histórica; um ato instintivo do poder no sentido de sua conservação; uma demonstração do amadurecimento dos políticos, decorrente da desastrosa vivência democrática; e um testemunho da lei eterna da ação, da reação e do progresso ${ }^{30}$. O período de hegemonia dessa reação se completaria apenas em 1851 - pois o "poder estava muito forte para aceitar imposições da democracia" - razão da derrocada das rebeliões de 1842 e 1848. Impulsionados pela insensata "vertigem revolucionária" dos movimentos europeus e pela impaciência das paixões, os rebelados ignoraram a negociação, a razão pública e os recursos da Constituição ${ }^{31}$.

Contudo, o domínio daquelas rebeldias resultou de repressão severa ditada pela "política de conciliação" - da qual o próprio Justiniano parece ter discordado 32 - uma espécie de pacto inspirado no lema latino "Poupar submissos e debelar soberbos", anunciado pelo ministério Macaé (José Carlos Pereira de Almeida Torres) em 1844, praticado pelo gabinete Olinda (1848-1850) e consolidado pelo gabinete Paraná (Honório Hermeto Carneiro Leão: 1853-56). Ele preservou as prerrogativas da Coroa e a unidade do império contra a "vertigem" revolucionária de matiz liberal ou republicano, e contra o "regresso ao absolutismo", engajando políticos moderados de ambos partidos na tarefa de administrar a política brasileira ${ }^{33}$ e proteger a

29 Ibid., p. 195-198.

30 Ibid., p. 198-199.

31 Ibid., p. 168.

$32 \mathrm{O}$ texto "Ação, reação, transação..." foi divulgado às vésperas das eleições de 1855 . O autor integrava o grupo de conservadores que fazia oposição às reformas implementadas por Honório Hermeto Carneiro Leão, Marquês de Paraná, especialmente os métodos da "conciliação" e a reforma eleitoral. Suas discordâncias com o gabinete, sutilmente insinuadas neste texto, e sua inspiração hegeliana foram abordadas por JANOTTI, Maria de Lourdes M. A falsa dialética. Revista Brasileira de História, v. 2, n.3, p. 3-17, mar. 1982. A matriz hegeliana, o caráter circunstancial do texto e o envolvimento do jornalista com o então ministro da justiça Nabuco de Araújo, seu possível solicitador, foram analisados por GUIMARÃES, Lúcia M. Paschoal. Ação, reação, transação: a pena de aluguel e a historiografia. In: CARVALHO, José Murilo (Org.). Nação e cidadania no Império: novos horizontes. Rio de Janeiro: Civilização Brasileira, 2007, p. 71-92.

33 CASTRO, Paulo Pereira de. A política de 1840 a 1848. In: HOLANDA, Sérgio Buarque de. (Org.). O Brasil monárquico. História Geral da Civilização Brasileira. São Paulo: Difel, Tomo II, 2. ${ }^{\circ}$ v., 
missão histórica do jovem imperador Pedro II, cuja imagem era concebida pelos membros do recém-fundado IHGB como "o Príncipe perfeito porque não empunhara a espada ou o sabre, para consolidar a sua Coroa; e que faria da tolerância e do culto ao intelecto suas principais virtudes" ${ }^{\prime 34}$.

Segundo Lúcia Guimarães, o IHGB teria importante papel na "invenção de uma tradição" que fez do estado monárquico o "legítimo herdeiro e sucessor do império ultramarino lusitano [...] herança que se sustentava inclusive com a presença no trono brasileiro de um representante da Casa de Bragança" 35 . A preocupação de ali se produzir uma história "pragmática e filosófica" para a pátria também determinou a busca de explicações e soluções para problemas do presente ${ }^{36}$, como a escravidão africana, a catequese indígena, o destino das ordens religiosas e o apaziguamento das rebeliões. Tais desígnios aflorariam em polêmicas internas, no conteúdo das memórias históricas encomendadas e em trabalhos de grande fôlego, chancelados ou não pelos condutores da instituição ${ }^{37}$, a

1964, p. 508-540. Dentre os "moderados" que apoiaram a Maioridade e também a Conciliação, sobretudo em seus primeiros anos, estavam fundadores do IHGB. Constituíam os "áulicos", grupo que aglutinou, ainda no período regencial, políticos liberais e restauradores próximos da família real. GUIMARÃES, Lucia M. Paschoal. Debaixo da imediata proteção de imperial: o Instituto Histórico e Geográfico Brasileiro (18381889). Revista do IHGB. Rio de Janeiro, n. 388, jul./set. 1993, p. 481-6.

34 GUIMARÃES, Lucia M. Paschoal. O Império de Santa Cruz: a gênese da memória. In: HEIZER, Alda; VIDEIRA, Antonio Augusto Passos (Orgs.). Ciência, civilização e império. Rio de Janeiro: Access, p. 281-82.

35 GUIMARÃES, L. M. P. Debaixo da imediata proteção de imperial. Op. cit., p. 523.

36 "Sendo innegavel que as lettras, além de concorrerem para o adorno da sociedade, influem poderosamente na firmeza de seus alicerces, ou seja, no esclarecimento de seus membros, [...] são as lettras de uma absoluta. [...] necessidade, principalmente aquellas que, versando sobre a historia e geographia do paiz, devem ministrar grandes auxílios á publica administração para o esclarecimento de todos brazileiros." Breve Noticia sobre a creação do Instituto Histórico e Geographico Brazileiro, (Revista do IHGB, 1839, tomo 1, p. 5). As diferentes matrizes teóricas do projeto para uma história nacional proposto pelos fundadores do IHGB, assim como seu diálogo com uma cultura historiográfica dos oitocentos foram demonstradas por: GUIMARÃES, Manoel Salgado. A disputa pelo passado na cultura histórica oitocentista no Brasil. In: CARVALHO, José Murilo (Org.). Op. cit., p. 93-122; e CEZAR, Temístocles. Lição sobre a escrita da história. Historiografia e Nação no Brasil no século XIX. Diálogos, Maringá, v. 8, n. 1, p. 11-29, 2004.

37 Lúcia Guimarães registra o trabalho de censura política e interpretativa praticada especialmente nas duas primeiras décadas do IHGB. Assim, determina-se o arquivamento numa "arca do sigilo", para publicação em tempo oportuno, dos textos que tratem de "circunstâncias muito recentes de nossa história". Também não se promove propostas que contrariem teses ali aceitas: o indianismo e a hegemonia das raízes europeias da nação. Segundo a autora, essas diretrizes explicariam a pequena atenção dada ao texto de Von Martius, "Como se deve escrever a história do Brasil", assim como a "frieza" com que foi recebida a História Geral do Brasil, de Varnhagen. GUIMARÃES, Lúcia M. Paschoal. Debaixo da imediata proteção de imperial: o Instituto Histórico e Geográfico Brasileiro (1838-1889). Revista do IHGB. Rio de Janeiro, n. 388, p. 558, 571, 574. jul/set. 1993. Contudo, a repercussão da proposta de Von Martius 
exemplo das obras João Manuel Pereira da Silva ${ }^{38}$ e, sobretudo, de Francisco Adolfo de Varnhagen. Fundamentando-se em copiosa documentação que recolhera na Europa, elogiou, na História Geral do Brasil (1854-57), os feitos dos grandes personagens da colonização (a coroa, os administradores, os donatários e os bandeirantes), construtores de inédito império. Mas, também registrou conflitos, dificuldades e as decisões problemáticas para o futuro, em parte responsáveis pela singularidade da nação: as grandes concessões feitas aos donatários e sesmeiros (em terras e direitos) e aos jesuítas (o domínio sobre os índios e seu trabalho) lhes teria franqueado autonomia política e material - fundamento das insubordinações contemporâneas - e imposto a escravidão africana, ao invés da indígena, ponto maior da dessemelhança com a metrópole e as nações europeias. O livro ainda estabeleceu marcos e demonstrou uma concepção da independência legitimadora do império e da dinastia dos Braganças:

As concessões outorgadas pelas cartas de doação [...] são mais latas do que se devia esperar em uma época em que na Europa os reis tratavam de concentrar cada vez mais a autoridade [...] Os meios feudais tinham sido, porém, os mais profícuos para colonizar os países ermos de gente [...] Quase podemos dizer que Portugal reconhecia a independência do Brasil antes de ele se colonizar [...].

É certo que a mania de muita terra acompanhou sempre pelo tempo os sesmeiros e acompanha ainda nossos fazendeiros,

no IHGB, sua presença na obra de Varnhagen, assim como a aceitação da interpretação desse historiador no Instituto, são temas ainda polêmicos entre os analistas da historiografia brasileira do século XIX. WEHLING, Arno. Estado, história e memória: Varnhagen e a construção da identidade nacional. Rio de Janeiro: Nova Fronteira, 1999; GUIMARÃES, Manoel Salgado. Nação e civilização nos trópicos: o IHGB e o projeto de uma história nacional. Estudos Históricos. Rio de Janeiro, n. 1, 1988; CEZAR, Temístocles. Como deveria ser escrita a história do Brasil no século XIX. Ensaio de história intelectual. In: PESAVENTO, Sandra J. et al. (Orgs.). História cultural: experiências e pesquisa. Porto Alegre: Ed. UFRGS, 2003.

38 Os varões ilustres do Brasil durante o periodo colonial (1858); História da fundação do império brasileiro de 1808 a 1825 (1864-68, 7 v.); Segundo periodo do reinado de Pedro I: de 1825 a 1831 (1871); História do Brasil de 31 a 40. Governos regenciais durante a menoridade (1878). Os trabalhos sofreriam muitas críticas pelas imprecisões históricas. Joaquim Nabuco o consideraria "um improvisador

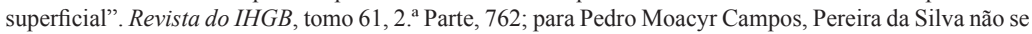
aproximaria do espírito crítico de Varnhagen nem das preocupações marcantes do movimento historiográfico europeu de meados do XIX. Era um crítico da escola criada por Mignet, desenvolvida por Thiers e Armand Carol, nascida das teorias da revolução francesa de 1789, pois ela "estraga a vida, desmoraliza a consciência e perturba o espírito". CAMPOS, P. M. Op. cit., p. 269. 
que se regalam de ter matos e campos em tal extensão que levam dias a percorrer-se, bem que às vezes só a décima parte é aproveitada [...].

O reino de novo criado, [em 1815] - pelo benéfico rei D. João - era nada menos que o centro e cabeça de um grande império, maior que os dois romanos [...] E menos ainda lamentamos que não se conte desde 1817 a madureza da independência, nós que a fazemos proceder da carta régia sobre o franqueio dos portos, $\mathrm{e}$ por conseguinte ao mês de janeiro de 1808; e portanto com mais glória para o Brasil, que destarte remonta a sua emancipação colonial da Europa a uma época anterior a todas as repúblicas continentais hispano-americanas ${ }^{39}$.

Consolidada a unidade da nação, a década de 1860 permitiu mais liberdade para o debate sobre o passado, envolvendo os integrantes do IHGB. Também restaurou a presença liberal no Parlamento e retomou a discussão sobre os problemas do regime, as falhas da colonização e a singularidade do país, temas tratados na Circular aos Eleitores, divulgada pelo veterano político liberal Teófilo Ottoni em 1860. Nela, a independência e a revolução do 7 de abril expressaram imagens positivas já consagradas por Armitage e Timandro, ou seja, haviam sido sinônimo de progresso, das conquistas do século e ponto de chegada almejado por políticos moderados e consequentes como o próprio Ottoni e outros parlamentares. Mas, conforme asseverara Justiniano, a sociedade estava despreparada para realizá-la. Tal despreparo se expressou nos equívocos dos ministros e parlamentares que confundiram o Poder Moderador com o poder pessoal do governante, inviabilizando a prática de uma verdadeira monarquia constitucional. Retomando argumentos de Armitage e Justiniano, concluiu que "300 anos de escravidão não podem preparar um povo para entrar no gozo da mais perfeita liberdade" ${ }^{40}$. O cativeiro criara "um povo acomodado na ignorância e no despotismo",

39 VARNHAGEN, Francisco A. de. História geral do Brasil. Antes de sua separação e independência de Portugal. 10. ed. integral. B. Horizonte: Itatiaia; São Paulo: Edusp, 1981. v. 3 - Tomo V (desde a Regência do Príncipe d. João até a revolução Pernambucana de 1817). Tomo I, p. 150, 146; Tomo III, p. 149, 150-151.

40 OTTONI, Teophilo Benedito. Circular dedicada aos senhores eleitores de senadores pela província de Minas Gerais no quatriênio actual e especialmente dirigida aos senhores eleitores pelo 20 . districto eleitoral da mesma província para a próxima legislatura, pelo ex-deputado Teophilo Benedicto Ottoni. Prefácio de Basílio de Magalhães. 2. ed. Revista do I.H.G.B. Tomo LXXVIII (2. a parte), Rio de Janeiro: Imprensa Nacional, 1916. p. 71- 72. 
ao qual faltava instrução pública e moralidade política. Para prevenir o esfacelamento do país, Ottoni reiterou apoio à monarquia e à integridade do Império ${ }^{41}$.

Após as "desordens" ocorridas no Rio de Janeiro em 1831, o autor se convencera da "imaturidade" do país para realizar a revolução liberal, missão atribuída então aos representantes do povo no Parlamento. Tratava-se de reformas na Constituição visando construir uma "monarquia republicanizada" o mais próxima possível da república norte-americana e de seus pressupostos de cidadania e ordem ${ }^{42}$. Reconhecendo diferenças entre o Brasil, os Estados Unidos e a Europa, achava possível "republicanizar" o regime monárquico, restringindo atribuições do Poder Moderador e do Senado e desdobrando prerrogativas das assembleias provinciais, objetivos cristalizados no Ato Adicional de $1834^{43}$. Da mesma forma que Timandro, justificou a escolha da monarquia como uma opção política fundamentada na aclamação do povo e da Constituição, princípio de onde emanava todo o poder dos Braganças no Brasil. Essa batalha contra o Poder Moderador envolvera o deputado, um "democrata pacífico", em inúmeros episódios revolucionários no período entre 1840 e 1848 , e o teria feito retornar à política em 1858, depois de um "forçado" recesso do Parlamento ${ }^{44}$.

Rememorando, em 1860, seu comprometimento na "revolução paulista" de 1842, lamentou o "indeclinável" recurso, mas não deixou de frisar: apesar da guerra civil ser um expediente aceito pelo credo liberal, os liberais não a desejavam e a ela haviam sido constrangidos para dar um "basta" ao governo, defender seus direitos e a Constituição ${ }^{45}$. Por isso, em 1859 e 1860, continuava a bater forte contra o governo pessoal e as instituições que o sustentavam: a "seita palaciana", o Conselho de Estado,

$41 \mathrm{Ibid}$., p. 208.

42 Ibid., p. 69-70.

43 "Estamos intimamente persuadidos de que, se Washington, Franklin e todos os outros patriarcas da liberdade americana tivessem nas atuais circunstâncias o leme dos negócios do Brasil, eles nos encaminhariam assim". Ibid., p. 73-74.

44 "Afastando-se" do parlamento em 1849, Ottoni se dedicou, até 1857, à Companhia de Comércio e Navegação do Rio Mucury. Ver Cap. XII, p. 225-232. FERREIRA NETO, Maria Cristina Nunes. Memória, política e negócios: a trajetória de Theophilo Benedicto Ottoni. Tese (Doutorado) - Campinas, IFCH-Unicamp, 2002.

45 Fundamentou a resistência liberal conciliando renomados "publicistas"-Silvestre Pinheiro Ferreira, Vatel, Delolme, e mesmo o "legitimista" Chateaubriand - e referindo as seguintes obras: Droit constitucionel et pouvoir legislatif, de Pinheiro Ferreira; Droit des gens, de Vatel; e Constitution d'Angleterre, de Delolme. OTTONI, T. B. Circular dedicada... Op. cit., p. 174, 175, 179, 187. 
o Senado vitalício, os ministérios e, na sombra de todos eles, a "oligarquia tenebrosa comprometida com o tráfico". Mas, suas restrições não atingiram a pessoa do Imperador, "um homem culto e competente" com quem, enquanto parlamentar, se encontrara por várias vezes. O Imperador sozinho e a monarquia não podiam fazer mal. Responsabilizou os políticos ${ }^{46}$.

Alguns anos depois, em 1868, o debate se acirraria, estimulado pela projeção da "questão servil", por uma cisão interna que empurrou vários políticos conservadores para o partido liberal e pela fundação do partido republicano. Então, a argumentação crítica da monarquia e sua herança colonial, divulgada por Armitage, Timandro e mesmo Ottoni, foi retomada pelos "novos" partidos para reivindicar "reformas" liberais - o cerceamento ao Poder Moderador, mudanças na lei eleitoral e a abolição da escravidão - e divulgada em escritos de Tavares Bastos ${ }^{47}$, Perdigão Malheiro ${ }^{48}$ e em $O$ Abolicionismo, de Joaquim Nabuco ${ }^{49}$. Nesse texto e nas Conferências e comícios proferidos nas campanhas eleitorais entre 1884 e 1888, Nabuco destacou a problemática permanência do "antigo regime", na qual agigantou o "monopólio da escravidão" 50 . Partindo do pressuposto de que "a questão da democracia brasileira não era a monarquia, mas a escravidão", concebeu sua abolição como ponto de partida da grande "reforma regeneradora e pacífica" da sociedade, dos partidos e da monarquia ${ }^{51}$; seria uma "segunda

46 Ibid., p. 223.

47 BASTOS, Aureliano C. Tavares. Os males do presente e as esperanças do futuro. São Paulo: Nacional, 1939. (1. ed. 1861); Cartas do solitário. 3. ed. S. Paulo: Nacional, 1975. (1. ed. 1862); A Província. Estudo sobre a descentralização no Brasil. 2. ed. S. Paulo: Nacional, 1937. (1. ed. 1870).

48 MALHEIRO, Perdigão. A escravidão no Brasil. Ensaio histórico, jurídico, social. Intr. Edison Carneiro. 3. ed. Petrópolis: Vozes, 1976. 3 v. (1. ed. 1866-67).

49 NABUCO, Joaquim. O Abolicionismo. Londres: Typ. de Abraham Kingdon, 1883. As citações estão remetidas a: O Abolicionismo. Introdução de Marco Aurélio Nogueira. 5. ed. Petrópolis: Vozes, 1988; e Minha formação. Introdução de Gilberto Freyre. 5. ed. Brasília: Ed. UnB, 1963.

$50 \mathrm{Na}$ composição das categorias desse argumento Nabuco projetou imagens da escravidão, da servidão, da grande e pequena propriedades, da aristocracia e da decadência das civilizações grega e romana inspiradas em escritores latinos (particularmente nos Anais e Germânia, de Tácito) e na História de Roma, do jurista, político e historiador liberal alemão Theodor Mommsen. TÁCITO, Cornélio. Anales (libros XI-XVI). Trad. José Moralejo. Madrid: Ed. Gredos, 1986; Germânia. Trad. J. M. Requejo. Madri: Ed. Gredos, 1999; MOMMSEN, Theodor. El mundo de los Césares. Trad. Wenceslao Roces. México: Fondo de Cultura Económica, 1995. (História de Roma, libro V). Nabuco citou especialmente trechos do cap. 1 desse volume, de título "Las províncias bajo Julio César", p. 7-50.

51 Propôs que a finalização da escravidão não fosse abandonada ao movimento natural da história como acontecera no Império Romano, nem ao alvedrio dos proprietários de escravos. Também não concordou com soluções extremas a exemplo da "guerra civil" ocorrida nos Estados Unidos; da "guerra servil", uma "incitação ao crime", remetido à desorganização do trabalho nos engenhos e fazendas incentivada por grupos abolicionistas que já instigavam fugas e revoltas nas senzalas. Tampouco admitiu "insurreições" ou rebeldias por iniciativa escrava NABUCO, J. O Abolicionismo. Op. cit., p. 27-28. 
independência" do país a ser realizada por um partido político no âmbito do Parlamento por meio de leis.

Em O Abolicionismo, a escravidão é concebida como um grande "crime": era uma ilegalidade perante o direito internacional, a legislação brasileira, a ética e as práticas econômicas liberais. Além disso, constituía um tentacular e asfixiante "monopólio" da terra e do trabalho que sustentava a grande propriedade territorial - os "latifúndios" - com "trabalhadores enclausurados" e "proletários" miseráveis, verdadeiros "servos da gleba", inviabilizando pequenas propriedades, classes operárias e uma "classe média" 52 . Ela era a responsável pelo esgotamento do solo, o aviltamento do trabalho, por uma riqueza estéril e efêmera reaplicada em escravos e no luxo e pelo sistema que arruinara o país por "não fomentar nenhuma indústria, não empregar máquinas, não concorrer para o progresso da zona circunvizinha $^{53}$, não criar consumidores, não desenvolver cidades porque o comércio era servo de uma classe, a dos produtores de café ${ }^{54}$.

Assim, o desenvolvimento social do Brasil fora oposto ao dos Estados Unidos, já que a escravidão não afetara a constituição daquele país, "mantendo a parte superior do organismo intacta" e os negros fora da sociedade. Aqui, todavia, fora mais hábil e não desenvolvera a prevenção de cor, fundamento de ordem e hierarquia, o que "degradou as classes" 55 . Dessa forma, dificultou a formação de uma verdadeira aristocracia, pois "a aristocracia territorial não é nem aristocracia do dinheiro, nem de nascimento, nem de inteligência, nem de raça"; e neutralizou as forças sociais: cooptou a Igreja, degenerou os funcionários públicos, verdadeiros "servos do Estado", repeliu a imprensa e a escola, e impediu a emergência da opinião pública ${ }^{56}$.

Em virtude disso, a escravidão também desvirtuara a verdadeira política liberal ${ }^{57}$ e a monarquia parlamentar criando uma "paródia de

52 NABUCO, J. "Segunda Conferência no Teatro Santa Isabel”, Recife, 1.11.1884. In: $O$ Abolicionismo. Conferências e Discursos Abolicionistas. São Paulo: IPÊ, 1949. p. 271.

53 Ibid., p. 120 .

54 NABUCO, J. O Abolicionismo. Op. cit., p. 129-130.

55 'Entre nós a escravidão não exerceu toda a sua influência apenas abaixo da linha romana da libertas; exerceu-a, também, dentro e acima da esfera da civitas [...] a unidade nacional faz pensar na soberba desordem dos mundos incandescentes”. Ibid., p. 126-127.

56 Ibid., p. 138-139, passim.

57 Ibid., p. 138-139; 34; "Segunda Conferência...”; Conferências e Discursos Abolicionistas. In: O Abolicionismo. Op. cit., p. 273. O liame entre escravidão e monopólio inspirou-se em Augustin Cochin, 
democracia", degenerando os partidos - tornando-os veículos de interesses e ambições pessoais de uma "casta de senhores" - e fazendo do sistema representativo um "enxerto de formas parlamentares num governo patriarcal", onde ministros, senadores e deputados viviam subjugados pelo poder pessoal do Imperador absoluto "como o Czar e o Sultão". Era isso o que efetivamente ocorria, embora o monarca estivesse no centro de um governo moderno e provido de todos os órgãos superiores e de Parlamento e tentasse desempenhá-lo da melhor forma possível ${ }^{58}$.

As críticas às instituições monárquicas vigentes e a contundência da caracterização negativa da singularidade do Império, divulgadas nesses discursos preparados para a campanha abolicionista, fariam com que permanecessem esquecidos até a década de 1930, quando se retomou uma tradição crítica da monarquia. A obra de Joaquim Nabuco mais conhecida nas primeiras décadas republicanas seria Um estadista do Império (1893-1897), uma biografia do ministro, senador e conselheiro José Thomaz Nabuco de Araújo, pai do autor. Ela (re)combinaria argumentos aqui tratados para traçar uma imagem positiva da monarquia e alertar contra "a fatalidade das revoluções jacobinas", então identificadas com o "golpe militar" que derrubara o Império e prosseguira nos governos de Deodoro e Floriano ${ }^{59}$. Contudo, Nabuco continuou a responsabilizar os monopólios herdados do "antigo regime" - o feudalismo, os latifundia e a servidão - pela emergência das revoluções, remetidas no livro aos episódios da abdicação (o "7 de abril" de 1831) e, especialmente, à Revolta Praieira de 1848.

O lema "reforma contra revolução", presente em O Abolicionismo, também presidiu a narrativa que periodizou a história da monarquia em dois grandes momentos: o primeiro, de afirmação da opção monárquica (18131840) e o segundo (1840-1889) - período do segundo reinado, a "Grande

que considerava a escravidão "um dos privilégios assegurados pelas metrópoles às colônias" e "pedra principal do pacto colonial”. COCHIN, A. L'Abolition de l'Esclavage. Font de France: Ed. Désormeaux, 1979, p. 228. A primeira edição é de 1861.

58 NABUCO, J. O Abolicionismo. Op. cit., p. 138-140.

59 As citações estão remetidas a NABUCO, J. Um estadista do Império: Nabuco de Araujo - sua vida, suas opiniões, sua época. 2. ed. São Paulo: Nacional; Rio de Janeiro: Civilização Brasileira, 1936. 2 v. Foi publicada em 3 volumes entre 1896-99. Realiza um minucioso trabalho de pesquisa de artigos de jornais, discursos e documentos que integravam o arquivo particular de Nabuco de Araújo. Apresentamos um estudo mais amplo do desempenho de Joaquim Nabuco como político e historiador em MARSON, Izabel A. Política e método em Joaquim Nabuco: tessituras da revolução e da escravidão. Uberlândia: Edufu, 2008. 
Era Brasileira" - de vivência plena do regime. Ainda, subdividiu grosso modo esta última etapa em três fases: 1840-1850, momento de consolidação da ordem interna com o fim das revoluções e o aperfeiçoamento do sistema parlamentar; 1850-1878, apogeu da monarquia, época de "lutas pacíficas e de conciliação política"; e, finalmente, 1879-1889, etapa de declínio devido à doença do Imperador, o retorno das agitações (abolicionista, republicana e militar) e o desaparecimento dos grandes estadistas. Obra de grande fôlego, expôs minuciosamente a atuação de Pedro II, de Nabuco de Araújo e de outros estadistas, o funcionamento da monarquia constitucional, o exercício do poder pessoal, as reorganizações partidárias, em especial a reforma do partido liberal (considerada como obra magna de Nabuco de Araújo) e o encaminhamento das principais questões da política interna - a Conciliação, o fim do tráfico, a emancipação gradual, a política financeira, a reforma eleitoral - e externa - as relações com a Inglaterra, a questão do Prata e a guerra do Paraguai.

Homenagear a memória do Imperador, dos estadistas, especialmente de seu pai - destacando seu perfil de "autêntico reformador liberal" -, e demonstrar a superioridade das orientações monárquicas sobre as republicanas parecem ter sido as razões mais evidentes do livro. Nabuco retomou o passado para demonstrar a adequação do regime às condições históricas e sociais do país, à feitura e progresso da nação e ao exercício do autêntico liberalismo. Nesse aspecto, contrapôs as vicissitudes da independência e, principalmente, do interregno regencial - momento de uma primeira experiência republicana - com a tranquilidade propiciada pelos cinquenta anos do segundo reinado. Para ele, a república de inspiração "girondina ou jacobina", sinônimo de anarquia, despotismo e risco à integridade do país, constituía o avesso da obra monárquica e já tivera, sem sucesso, sua chance histórica. Representou o Império como um ser vivo e articulou sua história combinando os depoimentos de Nabuco de Araújo, Armitage, Justiniano da Rocha e Ottoni com informações de outras fontes ${ }^{60}$. $\mathrm{O}$ apelo ao imaginário orgânico possibilitou uma analogia entre a vida do biografado e a da

60 Para os acontecimentos de 1822 a 1837 recorre também a: RAIOL. Motins políticos; ABREU E LIMA. Compêndio de História do Brasil; PEREIRA DA SILVA. História do Brasil de 1831 a 1840; MELLO MORAIS. A Independência; VISCONDE DE GOYANNA. Apontamentos da vida política do visconde de Goyanna; artigos do Correio Mercantil da Bahia e do Rio de Janeiro, e ao depoimento do barão de Penedo, Francisco Inácio Carvalho Moreira. 
monarquia, pressuposto que lhe permitiu conceber o testemunho daquele como experiência modelar na compreensão do percurso do regime e da prática liberal no Brasil.

Assim, a infância e a adolescência do estadista coincidem com o nascimento e a mocidade da nação, a saber, a independência e o período regencial ${ }^{61}$. Durante a regência, como qualquer patriota, o jovem acadêmico de Olinda fora "girondino, americano, melodramático". Mas logo tornarse-ia francamente "reacionário", pois a revolução brasileira, ardentemente preconizada, perdera todo "encanto", transfigurada em tirania e despotismo $0^{62}$. Nabuco assinala, como Justiniano José da Rocha, o contraste entre a segurança do primeiro reinado - onde se gozou da "proteção de um monarca domador de ambições" - e a situação de risco implantada pelo 7 de abril, um grande engano para toda a sociedade ${ }^{63}$, contrapondo o comportamento irrefletido e despótico dos revolucionários - "ignorantes do sistema constitucional" - com a "magnanimidade" do Imperador na abdicação, no respeito à Constituição e no contorno da guerra civil. Observa que se a situação tivesse sido conduzida por verdadeiros estadistas - homens de saber, experiência e bom senso, cujo exemplo maior era o do próprio monarca -, e não tivesse imperado a impaciência dos exaltados, poder-se-ia ter evitado a forma tumultuada do desfecho a que se chegou, até porque "a revolução do 7 de abril conseguiu apenas impor subitamente a Pedro I uma solução que já estava aceita por ele". Fora um "desquite amigável", uma medida serena e racionalmente

61 Há uma coincidência entre os marcos da vida do personagem e da monarquia. Em 1823, acontecem as guerras da independência e a morte da mãe de Nabuco de Araujo; em 1831, a abdicação e o ingresso do biografado na Academia de Olinda; em 1840, a maioridade e o casamento do jovem político; em 1850, a afirmação do Império e o reingresso de Nabuco de Araujo na vida parlamentar; em 1878, o desaparecimento do senador e o início do declínio do regime. NABUCO, J. Um estadista... Op. cit., p. 4-6. v.1.

62 "No começo das revoluções liberais, esposá-las é o impulso natural da mocidade; não assim abafar mais tarde as suas indignações e nas suas afinidades todas para se subjugar inteiramente ao partido vencedor. O entusiasmo do primeiro momento é uma expansão, e nada custa; custa, porém, muito, a solidariedade dos dias subseqüentes, quando a revolução, às primeiras dificuldades que só ela opõe a si mesma, arroga-se o direito de salvar o seu princípio político arrasando a sociedade, si tanto for preciso." Ibid., p. 15.

63 "A fatalidade das revoluções é que sem os exaltados não é possível fazê-las e com eles é impossível governar. Cada revolução subentende uma luta posterior e aliança de um dos aliados, quase sempre os exaltados, com os vencidos. A irritação dos Exaltados trará a agitação federalista extrema, o perigo separatista, que durante a Regência ameaça o país de norte a sul, a anarquização das províncias". Ibid., p. 21. 
cogitada que lhe assegurou o trono português, seu dever paternal e "seu papel histórico de herói de dois mundos" ${ }^{94}$.

A interpretação do autor sobre os eventos do 7 de abril e a regência reiterou um argumento essencial na tese que relacionou fortemente liberalismo e monarquia e rejeitou a república sob sua forma americana, encontrada nos textos de Timandro e Ottoni. Porém, menos condescendente que Armitage, Justiniano e Ottoni no trato com os moderados, Nabuco descartou a ideia de que tivessem feito algo pelo liberalismo no Brasil - apenas resistiram "à anarquia que eles mesmos haviam provocado". E concluiu -a "experiência republicana" não tinha contribuído para a autêntica causa liberal. Pelo contrário, ameaçara a existência do país que, com a reação de 1837 e a maioridade (1840), retornara "suavemente" à monarquia. Contudo, apesar de seus riscos, havia sido uma etapa natural e necessária para atingir a idade adulta. "A agitação desses dez anos produz a paz de cinquenta que se lhe vão seguir". Elas cumpriram uma função histórica: "desprender o sentimento liberal da aspiração republicana" ${ }^{65}$.

Considerou os anos de 1840 a 1848 como de "aperfeiçoamento da monarquia parlamentar", questionada novamente pela Revolução Praieira ${ }^{66}$. Diferindo de Timandro e Ottoni e ampliando a leitura de Justiniano, Nabuco criou uma outra interpretação para aquele evento, apoiando-se especialmente no depoimento do pai, adversário e juiz dos rebeldes ${ }^{67}$. Avaliando o "caráter da agitação praieira", concluiu que a revolução explodiu devido a uma confluência de razões: por um lado, à falta de traquejo e oportunismo dos políticos praieiros e, por outro, à peculiar situação da sociedade pernambucana. $\mathrm{O}$ evento foi figurado pela aproximação de imagens das revoltas da plebe romana com traços da revolução francesa: ter-se-ia originado nas paixões e instintos constitutivos do comportamento das massas quando instigadas por demagogos (o partido da Praia), e no abuso das classes "que se servem das delongas da lei para preservarem seus privilégios",

64 Ibid., p. 18-19.

65 Ibid., p. 25.

66 Ibid., p. 30.

67 Os opúsculos: As eleições para senadores em Pernambuco e Justa apreciação do predomínio praieiro ou história da dominação da Praia. Typ. União, 1847. Utilizou também a história da rebelião escrita pelo Chefe de Polícia da Província Jerônimo Martiniano Figueira de Melo - Chronica da Rebelião Praieira. Recife: Tip. M. F. de Faria, 1850, além de muitos artigos de jornais. Cf. MARSON, I. A. O Império do Progresso: a Revolução Praieira em Pernambuco - 1842-1855. São Paulo: Brasiliense, 1987. 
monopólios remanescentes do antigo regime: o domínio dos portugueses no comércio e de uma "feudalidade territorial", os senhores de engenho, que monopolizaram a terra no interior" ${ }^{"}$.

Ela progrediu devido aos erros do partido praieiro na orientação do movimento e do gabinete Olinda em sua repressã $0^{69}$. Mas, para ele, a revolução não se tornaria vitoriosa, pois, diferentemente de Timandro e de Ottoni, Nabuco não acreditava que a situação do Brasil pudesse se assemelhar à dos Estados Unidos ou à da Europa daquele momento. $\mathrm{Na}$ verdade, a rebelião se remetia aos equívocos da prática liberal jacobina: a impaciência em aguardar a sua vez na sequência dos partidos, prevista no jogo parlamentar; o hábito de copiar as experiências estrangeiras inspirandose na proclamação da República na França e no "fermento socialista"70; e a falta de coesão entre as lideranças do partido. Também creditou o fracasso à atuação enérgica e oportuna de dois administradores da província, o presidente Manoel Vieira Tosta e o juiz Nabuco de Araújo; à experiência adquirida pelo partido liberal para "resignar-se à vez do adversário", e ao fato de o tempo das revoluções ter-se esgotado, pois "o organismo abalado precisava refazer-se pelo sono. [...] Pressentiu-se que esta seria a última das revoluções"

Assim, Nabuco espelhou a história da sociedade monárquica no percurso dos seres vivos e em figuras da história romana, referencial importante no apontamento da singularidade do país frente à Europa: ainda na adolescência, demonstrava um enorme despreparo para o exercício da política civilizada, sendo, portanto, presa fácil dos demagogos e das rebeldias. Tal "singularidade" foi um argumento essencial para explicar as limitações e, sobretudo, o perfil "desvirtuado", negação do self government que a monarquia vivenciara no Brasil. Alterando considerações apresentadas em $O$ Abolicionismo, observou que a recorrente intervenção do Imperador no jogo parlamentar (na montagem dos gabinetes, na atuação dos estadistas, nas decisões do Senado e da Câmara e no desempenho dos Partidos) e a farsa eleitoral eram práticas problemáticas, sem dúvida. Porém, haviam sido necessárias. Heranças do passado, em especial do domínio de instituições do

68 NABUCO, J. Um estadista... Op. cit., p. 75, v. 1.

69 Ibid., p. 69.

70 Ibid., p. 66-67.

71 Ibid., p. 73. 
antigo regime - o latifúndio, a servidão e da escravidão -, haviam impedido o desenvolvimento de uma opinião pública e criado uma sociedade imatura, desorganizada e dependente do governo. Nessas circunstâncias, o Imperador soubera compreender as solicitações do país e tornara-se a sua "consciência", papel que desempenhou exemplarmente, pois "onde D. Pedro II naufragou qualquer outro naufragaria antes dele e talvez de pior modo" "72.

\section{2. (R)evoluções incompletas}

Um estadista foi escrito em meio a sangrenta guerra civil - a Revolta da Armada (1893-94) e a Guerra de Canudos (1896-1897) - e intensa polêmica política e histórica sobre a experiência monárquica e o advento da república ${ }^{73}$. Enquanto os monarquistas consideraram a implantação do novo regime um "golpe de estado" alheio à vontade do povo e às necessidades da nação, decorrente da indisciplina do exército, do ressentimento do clero e de fazendeiros prejudicados pela abolição da escravidão, os republicanos retomaram velhas críticas à monarquia - sua "exótica" presença na América, o apoio no "despotismo" do Poder Moderador e na corrupção política - e defenderam a república como meta histórica, longamente protelada ${ }^{74}$. Em leitura mais conciliadora, Euclides da Cunha tornou-a etapa da evolução do país, ou a última das "revoluções" espelhadas no liberalismo europeu. Assim, a monarquia e seus competentes estadistas - figuras colocadas acima dos soberanos -, teriam sido essenciais na administração da incipiente herança

72 Ibid., p. 375-385.

73 Foram publicados no período: OTTONI, Christiano. O advento da República no Brasil. Rio de Janeiro: Perseverança, 1890; BUARQUE, Felício. Origens republicanas. Estudos de gênese política em refutação ao livro do sr. Afonso Celso, o Imperador no Exílio. Recife: Francisco Soares Quintas Ed., 1894. Por sua vez, os monarquistas escreveram: CELSO, Afonso. Advento da ditadura militar no Brasil. Paris: E. Pichon, 1891; PRADO, Eduardo. Fastos da ditadura militar no Brasil e A ilusão americana. São Paulo: Escola Typographica Salesiana, 1902; PEREIRA DA SILVA, J.M. Memórias do meu tempo. Rio de Janeiro: Garnier, 1895-6. 2 v.; NABUCO, J. Balmaceda. Rio de Janeiro: Typ. Leuzinger, 1895; A intervenção estrangeira durante a Revolta da Armada. Rio de Janeiro: Typ. Leuzinger, 1896; Um estadista do Império. Nabuco de Araújo, sua vida suas opiniões, sua época. Rio de Janeiro, Paris: Garnier, 1897-99. 3 v.

74 COSTA, Emília Viotti da. Sobre as origens da República. In: Da monarquia à república: momentos decisivos. 2. ed. São Paulo: Ciências Humanas, 1979, p. 243-251. 
colonial, pois teriam preservado, na independência e nos dois impérios mediados pela regência, um território imenso, ainda que impreciso; a unidade sempre ameaçada de províncias dispersas e de "agrupamentos étnica e historicamente distintos", preparando-os para a ordem republicana:

Com efeito, legislar para o Brazil em 1823, seria tudo menos obedecer á consulta lúcida do meio. [...] Porque nossa única tradição generalizada era a do ódio ao dominador recente ainda em armas [...] erguer unido, ao regime constitucional, novo na própria Europa, um povo disperso, que não atravessara uma só das fases sociais preparatórias. Um salto desmesurado e perigoso. A execução temerária da mais grave das revoluções [a independência] essa paradoxal "revolução pelo alto", que o gênio de Turgot, poucos anos antes, concebera, como recurso extremo para salvar Luís XVI [...] E nas aperturas desta alternativa a intervenção monárquica foi decisiva, oportuna e benéfica. [...] Assim, a nossa evolução, por ser estrictamente política, era problemática. Pelo menos ilusória. Estava numa minoria educada à européia. $\mathrm{O}$ resto jazia no ponto em que largara a metrópole, obscura e dúbia - amálgama proteiforme de brancos, pretos e amarelos, uns e outros prática e moralmente prejudicados pela escravidão $[\ldots]^{75}$

A polêmica se adensou com denúncias dos republicanos frustrados com o novo regime - moderados e "jacobinos" - e a divisão dos monarquistas pelas acusações mútuas sobre responsabilidades na queda da monarquia, rivalidades pessoais e discordâncias sobre como reverter a ascensão republicana ${ }^{76}$. Nesse sentido, pode-se considerar que Um estadista respondeu a insinuações de João Manuel Pereira da Silva, ex-senador saquarema, que também historiou o Segundo Reinado em Memórias de meu tempo para comprovar a desastrosa atuação dos liberais, em especial

75 CUNHA, Euclides. Da Independência à República. Revista do IHGB. Rio de Janeiro: Imprensa Nacional, 1908. Tomo LXIX. Parte II, p. 26-27; 41.

76 Sobre a atuação dos monarquistas e radicais jacobinos após o 15 de novembro ver JANOTTI, Maria de Lourdes. Os subversivos da República. São Paulo: Brasiliense, 1986; e QUEIROZ, Suely Robles de. Os radicais da república. São Paulo: Brasiliense, 1986. Ver também, COSTA, E. V. Da monarquia à república. Op. cit.; e LAPA, Jose R. do Amaral (Org.). História política da República. Campinas-SP: Papirus, 1990. 
na abolição. Contudo, a representação do Império de maior repercussão no início do século XX foi $A$ década republicana ${ }^{77}$, obra coletiva de expoentes monarquistas que fez "um balanço dos desacertos das políticas públicas republicanas em comparação com a obra grandiosa do Império":

Com a estrutura de um grande livro de História, recheado de referências documentais, esse libelo político enfeixa [...] marcantes representações sobre o passado monarquista, construtor da Nação e do Estado nacional e o presente republicano seu destruidor. [...] Primeiramente, cuidou-se de tornar a pessoa do Imperador e as referências à família real as mais discretas possíveis. Ao inverso do que acontecia nas demais publicações monarquistas, em A Década Republicana as personagens são absorvidas pelo sistema monárquico, visto este como tema central. [...] todos os membros do corpo legislativo do Império eram dignos, preparados e brilhantes, todos os chefes dos Gabinetes eram impolutos e de elevado tirocínio político. [...] O Império é representado como uma unidade temporal, material e moral. Algumas vezes o discurso remonta a 1808, outras vezes ao reinado de $\mathrm{D}$. Pedro I e à Regência, mas sempre se centralizando no II Reinado. Esforça-se por comprovar a continuidade dos progressos materiais, sem que conflagrações graves tivessem desviado os governos monárquicos do seu grande objetivo: tornar o Brasil a maior potência da América do Sul e reconhecido, entre as nações européias, como país civilizado e distinto das republiquetas do continente. Em outros termos, o Império havia dado aos brasileiros uma identidade nacional ${ }^{78}$.

Segundo Maria de Lourdes Janotti, a projeção dessa leitura deveu-se à articulação de um "diálogo convergente" político e historiográfico - possível pelo controle dos "jacobinos" civis e militares no governo Campos Sales - que aproximou alguns desiludidos com o novo regime, monarquistas e republicanos de origem aristocrática, notadamente representantes dos cafeicultores paulistas e das oligarquias estaduais contempladas pela "política dos governadores" ${ }^{\text {" }}$. O consenso acordado por intelectuais que criaram a

77 A década republicana. Rio de Janeiro: Companhia Tipográfica do Brasil. 1889-1901, 7 v.

78 JANOTTI, M. L. Os subversivos da república. Op. cit., p. 212.

79 JANOTTI, Maria de Lourdes. O diálogo convergente: políticos e historiadores no início da república. In: FREITAS, M. C. (Org.). História brasileira em perspectiva. Op. cit., p. 142. 
ABL e dirigiram o IHGB $^{80}$ em momento de expansão dos nacionalismos ${ }^{81}$ não apenas reiterou a tradição positiva do Império e de seus estadistas na fundação da nacionalidade ${ }^{82}$ como, na explicação de sua queda, destacou teses positivistas e cientificistas: a inevitabilidade dos acontecimentos, a "evolução" do país, ou, ainda, questionou o vínculo exclusivo entre a nação e o regime monárquico ${ }^{83}$. Tal consenso se revela claramente nos trabalhos do diplomata republicano que aderiu à monarquia, Manuel de Oliveira Lima ${ }^{84}-$ D. João VI no Brasil (1908), Formação histórica da nacionalidade brasileira (1911), O movimento da Independência (1922) e O Império Brasileiro (1927). Embora destaquem a história política e a erudição, também associam argumentos geográficos, econômicos, sociais e culturais recolhidos seletivamente em variado conjunto de fontes, bibliografia e intérpretes da história do Brasi ${ }^{85}$. Sobretudo em Formação histórica da nacionalidade brasileira (originalmente

80 A Associação Brasileira de Letras foi fundada em 1895 como espaço de criação literária e científica distanciado dos embates políticos - tarefa então difícil para o IHGB, dado o vínculo com a monarquia - por intelectuais de várias tendências, dentre eles os historiadores Joaquim Nabuco, Oliveira Lima, Capistrano de Abreu e João Ribeiro. Ângela de Castro Gomes anota o perfil desses historiadorescientistas: "Erudito familiarizado com os arquivos, professor e homem de ação, com postos na carreira política e/ou diplomática. Homem do mundo, espírito cosmopolita por viagens, leituras e pesquisas, tinha, contudo, suas raízes na terra e nos problemas brasileiros". GOMES, Ângela de Castro. História e historiadores. A politica cultural do Estado Novo. Rio de Janeiro: Ed. FGV, 1996, p. 52, 55. Lúcia Guimarães registra tentativa de aproximação anterior entre sócios da ABL e do IHGB: o renascimento, em 1893, do jornal $A$ Semana, organizado por Valentim Magalhães e Max Fleiüss, e integrado por políticos e escritores de diverso matiz político. Cf. GUIMARÃES, Lúcia M. Paschoal. Da Escola Palatina ao Silogeu: Instituto Histórico e Geográfico Brasileiro (1889-1930). Rio de Janeiro: Museu da República, 2007, p. 43-45.

81 Cf. HOBSBAWM, Eric. Nações e Nacionalismo desde 1780. Trad. Maria Célia Paoli e Anna Maria Quirino. Rio de Janeiro: Paz e Terra, 1990; HOBSBAWM, Eric; RANGER, Terence (Orgs.). A invenção das tradições. Trad. Celina Cavalcante. Rio de Janeiro: Paz e Terra, 1997; GELLNER, Ernest. Nations et nationalisme. Paris: Payot, 1999.

82 Tal valorização veio superar o "deserto do esquecimento" a que fora relegado o Segundo Reinado e seus personagens nos primeiros governos republicanos, quando se privilegiou Tiradentes, a Inconfidência Mineira, José Bonifácio e Benjamin Constant. Proposição lançada por Joaquim Nabuco já em seu discurso de posse como sócio-efetivo em 25 de outubro de 1896. GUIMARÃES, L. M. P. Da Escola Palatina ao Silogeu. Op. cit., p. 79.

83 Aproximando liberalismo, república e monarquia, Joaquim Nabuco comentou no último capítulo de Minha formação: a essência do liberalismo não prendia necessariamente seus adeptos ao regime monárquico, mas ao dever de zelar pela pátria. NABUCO, J. Minha formação. 5. ed. Brasília: Ed. UnB, 1963 , p. 256-257.

84 Por discordar da política diplomática a favor do pan-americanismo de seu superior, o barão de Rio Branco, e também por questões pessoais. MALATIAN, Teresa. Oliveira Lima e a construção da nacionalidade. Bauru: EDUSC/Fapesp, 2001.

85 Utiliza documentos coloniais portugueses, espanhóis e holandeses; relatos de estrangeiros e correspondência diplomática, além das obras de Southey, Armitage, Justiniano José da Rocha, Timandro, Varnhagen, Euclides da Cunha, Capistrano de Abreu, João Ribeiro e Joaquim Nabuco. Em O Movimento da Independência e O Império Brasileiro ainda incorpora autores latino-americanos e espanhóis. 
conferências proferidas na Sorbonne), o percurso da nação torna-se uma evolução advinda de fatores orgânicos e históricos, destacando-se a atuação de uma aristocracia singular sem "preconceito de raça", com poder econômico e "senso de independência", e do Estado (metropolitano ou nacional), garantia de ordem e unidade política e territorial ${ }^{86}$. A emancipação política integra essa evolução, pois "as colônias tendem todas a emancipar-se de suas metrópoles. É a regra geral determinada pelo crescimento e pela ânsia de liberdade, regra que se estende do reino animal ao domínio social [...]. O antigo regime era pouco mais ou menos igual por toda parte" $"$.

$\mathrm{O}$ apoio em depoimentos estrangeiros possibilitou uma imagem da história nacional plenamente afinada com as experiências americanas e, dada a preservação da monarquia, vista como continuidade da história europeia, sobretudo da história francesa, com a qual o Brasil partilhara marcos revolucionários - 1789 (a Inconfidência Mineira); 1831 (a revolução liberal); 1870 (emergência do partido republicano). Assim, três momentos foram superados: a colonização (1500-1808); o reino-unido (1808-1822) criação de d. João VI, "o monarca sábio e prudente a quem o Brasil deve sua organização nacional" e unidade; e o Império (1822-1889), uma "democracia coroada" ou um "presidencialismo hereditário", original adaptação da monarquia parlamentar e do liberalismo, superior às repúblicas americanas ${ }^{88}$. Nesse último período, ter-se-ia aprimorado a nacionalidade brasileira, prudentemente moldada pelos soberanos da Casa de Bragança e estadistas

86 Destaca a iniciativa e trabalho dos colonos e ordens religiosas. Na origem desse senso de independência anota o poder advindo das generosas concessões da metrópole; a determinação na conquista da natureza bela mas hostil, que não pode prescindir da violência - atenuada pela sensibilidade de homens sem preconceito de raça - contra os índios (povos bárbaros e no geral ferozes); e na escravidão dos negros. Essa singular nacionalidade resultou num povo mestiço, um amplo e rico território e instituições adaptadas do feudalismo e absolutismo metropolitanos. LIMA, Manuel de Oliveira. Formação histórica da nacionalidade brasileira. Prefácios de G. Freyre, J. Veríssimo e M. E. Martinenche. 2. ed. Rio de Janeiro: Topbooks, 1997, passim.

87 Ibid., p. 123.

88 "O próprio império brasileiro foi democrático mais do que no rótulo, tanto que, ao organizar sua nobreza, não a fez hereditária [...] Efeito talvez da mestiçagem muito abundante, o fato é que aquele espírito igualitário predominou no Brasil mesmo através do império e que, senhores feudais como eram, pelo poderio que exerciam sobre seus dependentes, $[. .$.$] nunca deram mostras de querer aproveitar-se de sua$ posição e riqueza para com elas formarem a base de uma preponderância política [...] muito provavelmente porque sentiam pairar sobre eles a majestade da autoridade imperial [...] O Império foi pois desde o seu início [...] uma democracia coroada, em que o executivo começou por prevalecer e o legislativo acabou por predominar". LIMA, M. O. O Movimento da Independência. O Império Brasileiro. 4. ed. São Paulo: Melhoramentos, 1962, p. 30, 262, 316. 
"probos e ilustrados" amparados em Constituição adequada às necessidades do país, que conduziram sabiamente a nação em 4 momentos: na separação da metrópole (1822-1831), obra de Bonifácio e Pedro I, respectivamente "artífice político" e "condutor" do movimento de independência; nas Regências (1831-40), ocasião de medidas contra o tráfico, experimento de reformas legislativas descentralizadoras "prematuras" e de rebeldias dos exaltados, contornadas por Evaristo da Veiga, Feijó, Vasconcelos e Araújo Lima; na Maioridade e, sobretudo, na Conciliação dos partidos (1840-1860), fase de equilíbrio e prosperidade pela especial intervenção de Pedro II ("o mais nobre dos homens e o mais perfeito dos soberanos") e do marques de Paraná, "o criador da Conciliação". Primeiramente (184860), ela significou a "absorção do partido liberal exausto pelo conservador pujante"; depois (1869-1889), numa inversão, garantiu a expansão liberal - "ponto culminante do Império" - e do ideal republicano, coincidente com o esgotamento físico do Imperador e das instituições fundantes da monarquia - os partidos, o Exército e a Igreja - que, digladiando-se, desestabilizaram o regime ${ }^{89}$. O golpe de 15 de novembro interrompeu reformas liberais já em curso que concretizariam a monarquia federativa, segundo Lima, o pacto perfeito para o Brasil, ao menos naquele momento. Tendo já abolido a escravidão, previa o voto secreto dos cidadãos alfabetizados, a eleição dos presidentes de província e o senado temporário, com mandato de $9 \operatorname{anos}^{90}$. A veemência do historiador na valorização dos grandes personagens e das rebeldias conduzidas pela aristocracia - indicativas da evolução do país e amadurecimento dos ideais republicanos - é tão intensa quanto na recusa das manifestações populares, tidas por extravasamentos de instintos mestiços não domesticados de um "povo criança", ora dócil, ora turbulento, sempre sem "consciência de seus deveres e direitos":

Embalde adaptam as idéias da civilização a seu organismo; faltalhes o sentimento de que aquelas idéias pressupõem as virtudes e qualidades morais que, ao contrário das teorias, só a educação secular da história consegue a custo verter no espírito humano.

89 A interpretação dos principais episódios do Império acompanha, com sensíveis adaptações, Euclides da Cunha, citado em vários trechos (p. 127-129; 156-157; 189-190; 249-250). CUNHA, E. Da Independência à República. Op. cit.

90 LIMA, M. O. O Movimento da Independência. Op. cit., p. 365. 
[...] Em geral assimilam e preferem as teorias e os sistemas mais radicais porque esses são possíveis só com a demolição da sociedade; cortejam assim a civilização e ao mesmo tempo satisfazem o instinto fundamental que é, como o das crianças, puramente destrutivo. Sem o apoio moral dos costumes, as mutações do espírito são nelas rápidas e vertiginosas [...] Aqueles que descendem diretamente da escravidão ou da floresta viva nada têm com o passado que a prole deles, não tendo nobreza, não estima ${ }^{91}$.

O consenso expressivamente externado na interpretação de Oliveira Lima se solidificou pela aproximação entre os governos republicanos e o IHGB, ambos interessados na confecção de uma História do Brasil dotada de unidade e coerência, argumento essencial do patriotismo nacionalista. Não por acaso, a pesquisa histórica foi estimulada pelo Primeiro Congresso Nacional de História (1914), pela revitalização da memória de Pedro II, pela revogação do decreto de banimento da família imperial, translado (em grande manifestação) dos restos mortais dos imperadores (1921), e pelas comemorações do centenário da independência $(1922)^{92}$.

Contudo, nos anos seguintes instala-se um generalizado desencanto com a república liberal exteriorizado em crises políticas - decorrentes de desacertos entre as oligarquias ${ }^{93}$-, em levantes militares e civis, e em debates envolvendo intelectuais motivados por exacerbado nacionalismo, que se propuseram "conhecer", (re)interpretar e indicar soluções para os "problemas nacionais" remanescentes do passado: a "falta de coesão e densidade social"; de "órgãos aparelhadores que garantissem a unidade do país e de uma "consciência brasileira", ou seja, uma "nacionalidade suficientemente evoluída" ${ }^{4}$. Tal debate reacendeu a discussão sobre o melhor regime para o país, as razões da queda da monarquia e instalação da república, ensejando

91 LIMA, M. O. Formação histórica da nacionalidade brasileira. Op. cit., p. 144. A citação é de João Ribeiro, "o mais filósofo de nossos historiadores".

92 GUIMARÃES, L. M. P. Da Escola Palatina ao Silogeu. Op. cit., p. 123-124; 146.

93 A exemplo da crise desencadeada pela "Reação Republicana" (junho de 1921), que lançou a candidatura dissidente de Nilo Peçanha em oposição à oficial de Arthur Bernardes. Cf. FERREIRA, Marieta de Moraes. A reação republicana e a crise política dos anos 20. Estudos Históricos, v. 6, n. 11, 1993, p. 9-23.

94 CARDOSO, Vicente Licínio (Org.). À margem da História da República (ideais, crenças e afirmações). Rio de Janeiro: Ed. do "Annuário do Brasil”, 1924, p. 336. 
manifestos e publicações ${ }^{95}$, a exemplo da coletânea comemorativa dos 35 anos da república (1924) organizada por Vicente Licínio Cardoso, na qual revelam-se os objetivos de "uma geração que nasceu com a República", ciente da originalidade dos problemas brasileiros, desconfiada das "ideias exógenas", zelosa do progresso ordeiro e das "revoluções pacíficas":

Reunidos, representam uma geração de homens: a geração que nasceu com a República, pouco antes, pouco depois: não viram o imperador, não conheceram os escravos, não herdaram títulos, nem cargos, nem comissões. [...]. Agrupados apresentam todos uma característica comum: não estão presos a nenhuma escola européia, ou filiados a um sistema importado. Leram Spencer, Comte, Le Play, Karl Marx e outros, mas contrariamente aos predecessores da geração passada não são ortodoxos. Leram e admiraram por outro lado o nosso Alberto Torres, mas nenhum se intitula seu discípulo [...] São brasileiros: pensam pois como brasileiros: americanos, latinos, tropicaes. Demais estão todos proximamente de acordo sobre os pontos básicos de nossa história. Admiram com fervor a obra de José Bonifácio. [...] Conhecem Anchieta, a obra dos bandeirantes, Evaristo da Veiga, Feijó, Paraná, Nabuco, Mauá, Caxias, os dois Rio Branco, Benjamin Constant e Prudente de Moraes [...] respeitam, além disso a figura histórica de Pedro II, vendo nela a razão justificada do atraso com que foi instituído o regime republicano no Brasil. [...] Compreendem de outro lado a gravidade de nosso momento histórico presente e procuram reagir. Mas reagir pelo progresso dentro da ordem, por isso todos eles sabem que em sociologia o caminho seguro para andar mais ligeiro é aquele que evita os desatinos das correrias revolucionárias perigosas e intempestivas ${ }^{96}$.

95 A rigor, as discussões sobre a identidade brasileira, sua história e problemas ganham vigor a partir da guerra de 1914 e de seus resultados. Além das obras aqui mencionadas, um exemplo expressivo desse vigor pode ser reconhecido na fundação, sobrevivência e conteúdo da Revista do Brasil, dirigida por Monteiro Lobato. Cf. LUCA, Tânia Regina de. A Revista do Brasil. Um diagnóstico para a (N)ação. São Paulo: Ed. Unesp, 1999. Também nos manifestos então divulgados, a exemplo do Regionalista e do modernista Pau Brasil.

96 CARDOSO, V. L. (Org.). A margem da História da República. Op. cit., p. 14-15. Escreveram: A. Carneiro Leão: Os deveres das novas gerações brasileiras; Celso Vieira: Evolução do pensamento 
Foi na busca das origens dos problemas do país que se fez também um balanço historiográfico. Inspirando-se nas restrições de Capistrano de Abreu, Euclides da Cunha e Alberto Torres à "historiografia oficial do Império e da República" - particularmente os "seguidores" de Varnhagen e Pereira da Silva - Rio Branco, Rocha Pombo, João Ribeiro, Oliveira Lima, Joaquim Nabuco -, Licínio Cardoso sinalizou supostas limitações das análises que se cingiam aos fatos políticos, aos personagens e à corte, deixando à margem ocorrências econômicas, sociais, geográficas, raciais e culturais, assim como os agentes históricos e físicos que haviam efetivamente demarcado o território nacional, explorado riquezas, zelado por sua preservação - os bandeirantes, os sertanejos, os jesuítas, o exército:

O logro de Rio Branco e Mossé, em 1889, o de Nabuco, em 96, o de Rocha Pombo, quase em nossos dias são sintomáticos: vendo a pompa parlamentar acreditavam ingenuamente nela esses historiógrafos sem perceberem, no entanto que a política imperial parlamentar fora uma miragem enganadora, sem soluções, como ficaram os problemas essenciais e decisivos da nacionalidade ${ }^{97}$.

Infelizmente, porém, filiam-se os historiadores mais aos processos clássicos dos cronistas do que aos métodos modernos dos sociólogos. [...] Desse modo, desde trinta e cinco anos, assistimos ao relato dos acontecimentos republicanos de 89 à maneira das crônicas antigas, em que o autor em vez de descer à realidade dos fatos comenta por alto, na preocupação das citações dos nomes e dos detalhes das datas, ingênua e simplesmente os resultados do advento e da instituição do regime republicano entre nós. [...] Nem cuide o leitor que exagero quando insisto naquilo que tem passado desapercebido aos nossos historiadores em geral - a dependência em que estava o trono do escravo

republicano; Gilberto Amado: As instituições políticas e o meio social no Brasil; Jonathan Serrano: $O$ Clero e a República; José Antonio Nogueira: O ideal brasileiro desenvolvido na República; Nuno Pinheiro: Finanças Nacionais; F. J. de Oliveira Vianna: O idealismo na Constituição; Pontes de Miranda: Preliminares para a revisão constitucional; Ronald de Carvalho: Bases da nacionalidade brasileira; Tasso da Silveira: $A$ consciência brasileira; Tristão de Athayde: Política e letras; Vicente Licínio Cardoso: Benjamin Constant - o fundador da república è À margem da história da República. Contudo, o debate envolveu um grande número de indivíduos.

97 CARDOSO, Vicente Licínio. À margem da História do Brasil (livro póstumo). São Paulo: Nacional, 1933, p. 136. 
por intermédio do elemento nobre, elemento que era ao mesmo tempo, muitas vezes, senhor de terras e político militante. Penso mesmo que, essa falha no compreender os nossos verdadeiros fenômenos sociais (lastrando-os devidamente aos fenômenos econômicos) justifica a ausência de explicação da instituição da República no Brasil, por parte daqueles mesmos historiadores. Porque, não há negar, continua ainda por ser feita a história da República ${ }^{98}$.

A análise da monarquia feita por Licínio Cardoso preservou uma opinião positiva dos estadistas e, quase sempre, do Imperador, no esforço de agregar uma sociedade dispersa e desorganizada e manter a unidade nacional; sobre a contribuição dos portugueses, e suas limitações na colonização, e sobre a inadequação ao país das instituições europeias signatárias do liberalismo, em destaque o "abolicionismo". Apesar dessas certezas, algumas discordâncias se anunciaram entre os colaboradores da coletânea na avaliação do regime monárquico, pois o livro veio também dialogar com a obra coletiva comemorativa do centenário do nascimento de Pedro II realizada no $\mathrm{IHGB}^{99}$, matriz de trabalhos importantes - A política exterior do Império (de Pandiá Calógeras) e O ocaso do Império (1925), de Oliveira Vianna. Buscando os motivos da queda da monarquia, Vianna constata o insucesso tanto do regime monárquico quanto do republicano, reforçando a tese do desconcerto entre as teorias e práticas políticas europeias de qualquer matiz à realidade brasileira:

Os que concluíram [...] que o ambiente do país, anterior ao golpe de 15 de novembro, era universalmente republicano, incidiram em grave equívoco [...] Por essa época, o sentimento mais generalizado não era da crença na República, mas sim de descrença nas instituições monárquicas [...] o que se depreende do estudo do período [...] é que o espírito público havia atingido [...] em relação às instituições da Carta de 24 , um grau de ceticismo muito comparável ao que observamos atualmente

98 CARDOSO, V. L. À margem da história da República. Op. cit., p. 322, 330.

99 Contribuições para a Biografia de Pedro II. Revista do IHGB. Rio de Janeiro, Tomo especial, Parte I, 1925. Sobre a composição do tomo ver: GUIMARÃES, L. M. P. Da Escola Palatina ao Silogeu. Op. cit., p. 176. 
em relação à Carta republicana de 91 . Os homens daquele época haviam concebido um certo ideal de governo - ideal aliás, que nenhum deles havia procurado saber se era exequível ou não [...] Ora, este ideal, entretanto, falhou. O governo que saíra da Carta $[\ldots]$ era uma outra cousa $[\ldots]$ Nenhum deles sequer pensou em saber se esse outro governo não seria talvez o melhor $[\ldots]$ ou único governo possível aqui ${ }^{100}$.

Investigando as origens dessa dissonância entre o liberalismo e a realidade nacional, (re)interpreta traços raciais, históricos e comportamentais singulares do "caráter brasileiro" já sinalizados por Varnhagen, Nabuco, Euclides da Cunha e Oliveira Lima. Eles decorriam do estágio histórico em que se encontrava o país (no IV século de existência) e de práticas "originais" remanescentes da colonização, em especial do "latifúndio"101, razão maior da prevalência do rural sobre urbano; do espírito de clã frente ao interesse coletivo; de independência e altivez diante dos governantes; e a ausência de atitudes polidas e conciliadoras, o que os tornou "homens de partido" inábeis na condução das crises, exceção feita a alguns estadistas (Cotegipe, Saraiva, Paraná) e ao Imperador, sempre ponderado e correto na condução do regime parlamentar, em especial a alternância de partidos no poder. $\mathrm{Ou}$ seja, apesar de probos e leais, os políticos do Império comprometeram-se com interesses restritos e não mediram as consequências de suas pesadas críticas ao soberano e à monarquia, e do uso, à sua conveniência, das forças armadas. A essa inabilidade, somaram-se outras carências: um "povo" consciente de seus direitos e deveres; uma classe média consistente e uma opinião pública ${ }^{102}$.

100 VIANNA, Francisco de Oliveira. O ocaso do Império. 3. ed. Rio de Janeiro: José Olympio, 1959, p. 96-97. (1. ed. 1925)

101 "Desde a nossa vida econômica à nossa vida moral, sentimos sempre poderosa, a confluência conformadora do latifúndio; isto é, na realidade, o grande medalhador da sociedade e do temperamento nacional. [...] Criados em plena liberdade dos campos, acostumados a mandar e a ser obedecidos, esses grandes senhores não se podem afazer do servilismo. Não está na sua índole a obediência do cortesão. São eles que fundam a monarquia, mas o seu culto pelo monarca não chega nunca à servilidade." VIANNA, Oliveira. Populações meridionais do Brasil. História, organização, psicologia. B. Horizonte: Itatiaia; Rio de Janeiro: Ed. UFF, 1987. v 1, p. 54. (grifos do autor).

102 Estas teses são reiteradas em várias obras de Vianna: Populações meridionais do Brasil (1920); O idealismo na evolução política do Império e da República (1922), Evolução do povo brasileiro (1923) e O ocaso do Império (1925). 
Dessa forma, enquanto simpatizantes da monarquia - Oliveira Vianna e Pandiá Calógeras ${ }^{103}$ - destacaram as sequelas políticas da situação "inorgânica" da sociedade brasileira - o desempenho inadequado dos políticos e dos partidos e, especialmente, a crise militar estimulada liberais inconsequentes -, falas como a de Cardoso, insistiram em outras questões estruturais - o desmantelamento da escravidão e da classe que a sustentava; a precipitação do "abolicionismo"; o prestígio do exército junto à população, contraposto ao desprestígio da dinastia; a emergência de grupos urbanos, a adesão popular à causa republicana, além dos equívocos do Imperador ${ }^{104}$.

Outras restrições mais contundentes foram feitas por Manoel Bomfim, republicano, americanista, nacionalista extremado e polêmico, autor de vários livros nos quais apontou os "males de origem" do país, neles sublinhando o "parasitismo" do Estado português e a continuidade monárquica. Embora partindo das mesmas referências historiográficas de Cardoso - Capistrano, Euclides, Alberto Torres -, Bomfim incorporou Oliveira Martins, Southey, Armitage e outros viajantes para explicar lacunas da administração portuguesa após a Restauração de 1640 e exaltar a obra dos brasileiros no período colonial - grande referência na busca de soluções para os problemas do país no presente - por ter sido a "idade heróica" e original da nação, já plenamente configurada em virtude de sua riqueza e desempenho na expulsão dos holandeses. Indo além, retomou a argumentação crítica da monarquia bragantina (de Timandro e Ottoni), destacando tanto a maturidade do país quanto a "falsa" independência realizada em 1822:

Na América, foi a colônia de Portugal a primeira a afirmar-se como nacionalidade. De formação essencialmente ruralagrícola, sabendo aproveitar as populações indígenas, essa colônia se expandiu naturalmente, por virtude própria, ao ponto de ocupar todos os territórios que se lhe abriam [...] uma nova sociedade já nitidamente distinta do mundo português, organizada em vista da vida americana, [...] vantajosamente

103 CALÓGERAS, Pandiá. A politica exterior do Império. São Paulo: Nacional, 1927-1933, 3 v.; Formação histórica do Brasil. São Paulo: Nacional, 1935; e também MONTEIRO, Tobias. História do Império. Rio de Janeiro: Briguiet, 1927-29. $2 \mathrm{v}$.

104 CARDOSO, V. L. A margem da história da República. Op. cit., p. 323 e s. 
adaptada às condições cósmicas e históricas que lhe eram dadas. Por isso mesmo, potente e rica. [...] senhor que fora de toda a conquista ultramarina, mas radicalmente degradado no parasitismo de um comércio privilegiado, Portugal reaparece, tão incapaz para a vida de soberania livre e econômica como para reconquistar o antigo domínio; restaurado, ele se encontra no mundo com o recurso único de acarrapatar-se na colônia americana, e sobre ela assentou, por inteiro, a sua vida. [...] A definitiva degradação do Estado português já era nossa; e foi ao preço de guardar toda essa degradação, que obtivemos a independência. [...] a nós foi preciso absorver a própria ignomínia deles, para fazer uma independência em falso, tirada da traição de uns, da transigência e pusilamidade, ou estultice de outros. E veio a mentida Independência, para ser o começo da verdadeira, que não é completa, talvez ${ }^{105}$.

O vigor dessa crítica emerge ainda em "O Brasil na História" (1926), onde Bomfim denunciou a "história oficial" de Varnhagen e dos "sub-Varnhagens" (Pereira da Silva, Oliveira Lima) por "deturpar as tradições" ao ocultar a atuação do "povo" e dos verdadeiros "patriotas", como os revolucionários de 1817. Sensivelmente desiludido com a República e desistindo de uma "regeneração" do país pela educação, em "O Brasil Nação", redigido em 1928 e editado em 1931, admitiria que "o remédio" poderia estar numa revolução nos moldes da revolução mexicana" ${ }^{106}$.

105 BOMFIM, Manoel. O Brasil na América. Caracterização da formação brasileira. 2. ed. Rio de Janeiro: Topbooks, 1997. p. 381-383. (1. ed. 1929). Bomfim era médico de formação e foi professor e diretor do Pedagogium (órgão criado por Benjamin Constant) e diretor-geral da Instrução Pública do Distrito Federal. Segundo seus biógrafos e comentadores, apesar de muito conhecido em sua época por suas ideias sempre polêmicas, teria ficado esquecido nas décadas seguintes. LEITE, Dante Moreira. $O$ caráter nacional brasileiro. História de uma ideologia. 4. ed. São Paulo: Pioneira, 1983; SUSSEKIND, Flora; VENTURA, Roberto. História e dependência. Cultura e sociedade em Manoel Bomfim. São Paulo: Ed. Moderna, 1984; AGUIAR, R.C. O rebelde esquecido; tempo vida e obra de Manoel Bomfim. Rio de Janeiro: Topbooks, 2000.

106 BOMFIM, Manoel. O Brasil na história. Deturpação das tradições. Degradação política. Rio de Janeiro: Francisco Alves, 1931; O Brasil nação. Realidade e soberania nacional. Rio de Janeiro: Francisco Alves, 1931. 2 v. Contrapontuando Euclides da Cunha, Sílvio Romero e muitos outros, em $A$ América Latina-males de origem, de 1903, embora sem romper com parâmetros positivistas e cientificistas, Bomfim acentuou as razões culturais e históricas (o colonialismo e comprometimento das elites), e não as raciais e mesológicas, para explicar o "atraso" das populações latinoamericanas. Por isso, a educação seria instrumento essencial do progresso. Cf. NAXARA, Márcia R. Capelari. Estrangeiro em sua própria terra. Representações do Brasileiro 1870-1920. São Paulo: Annablume/Fapesp, 1998, p. 97 e s. 
A aceitação desse expediente não foi uma atitude solitária. $\mathrm{Na}$ verdade, pelo menos desde as rebeliões dos tenentes e da "ruptura institucional" ocorrida em 1930, com variado perfil, ele estava na ordem do dia ${ }^{107}$ incentivando outras leituras do Império, a exemplo daquelas produzidas por Gilberto Freyre, Sérgio Buarque de Holanda, Caio Prado Jr. e Werneck Sodré ${ }^{108}$, autores que instigaram o debate (re)elaborando o patrimônio de argumentos repassados das décadas anteriores. Conforme sinalizou Stella Bresciani, partilharam matrizes teóricas e pressupostos, verdadeiros "lugares comuns", com a discussão dos anos 20: a ideia de que, diferentemente dos Estados Unidos, a colonização do Brasil fora obra de uma metrópole racial e culturalmente mestiça, fronteiriça entre a Europa e a África; que os colonizadores e seus herdeiros atuaram em um meio físico exuberante, porém, inóspito, degradador e quase indecifrável para eles, até porque apreciavam um saber livresco inadaptado ao povo e ao meio e signatário de orientações e instituições políticas (o liberalismo e a monarquia parlamentar) distantes da realidade nacional ${ }^{109}$. Ainda, no que diz respeito às orientações teórico-metodológicas, lembramos que esses intérpretes reiteraram categorias disponibilizadas pela sociologia e a psicologia, explicativas dos eventos, personagens da história política e institucional (a "sociedade patriarcal", a "índole, ou "caráter do povo

107 'Nos anos trinta desse século, a história política brasileira foi marcada por forte instabilidade e por vivo debate: a década se inicia com uma ruptura institucional, consagrada desde então como revolução de 30, terminando sob a égide de nova ruptura, a decretação do chamado Estado Novo. Sob a perspectiva das instituições políticas, sem sombra de dúvida, esses são momentos de ruptura". BORGES, Vavy Pacheco. Anos 30 e Política: história e historiografia. In: FREITAS, M. C. (Org.). Historiografia brasileira em perspectiva. Op. cit., p. 160. Sobre os projetos de revolução desse momento ver: VESENTINI, Carlos Alberto; DECCA, Edgar de. A revolução do vencedor. Contraponto, n. 1. Belo Horizonte, 1978; VESENTINI, C. A. A teia do fato. São Paulo: Hucitec/História Social USP, 1997; DECCA, Edgar de. O silêncio dos vencidos. São Paulo: Brasiliense, 1981.

108 "A revolução de 30 preparou o terreno para uma nova cultura política que se definiu a partir de um redimensionamento do conceito de democracia, norteada por uma concepção particular de representação política e de cidadania; a revisão do papel do Estado se complementa com a proposta inovadora do papel do líder na integração das massas e da apresentação de uma nova forma de identidade nacional". CAPELATO, M. Helena. Estado Novo; Novas Histórias. In: FREITAS, M. C. (Org.). Historiografia brasileira em perspectiva. Op. cit., p. 189; OLIVEIRA, Lúcia Lippi de et al. Estado Novo: ideologia e poder. Rio de Janeiro: Zahar, 1982; e Elite intelectual e debate político nos anos 30. Uma bibliografia comentada da revolução de 30. Rio de Janeiro: FGV; Brasília: INL, 1980. Muito foi escrito sobre estes autores nos últimos anos. Um exemplo sugestivo é o Dossiê Intérpretes do Brasil - anos 30. Revista USP. São Paulo, v. 38, jun./ago. 1998, p. 6-93.

109 BRESCIANI, M. Stella. O charme da ciência e a sedução da objetividade. Oliveira Vianna entre intérpretes do Brasil. São Paulo: Ed. Unesp, 2005. p. 101-150. 
brasileiro"); e utilizaram fontes primárias - documentação oficial, cronistas, relatos de viajantes, textos literários - e autores que abordaram o Brasil desde o século XIX ${ }^{110}$.

Apesar dos partilhamentos, suas teses singularizam-se frente aos historiadores filiados ao IHGB e ao Estado Novo ${ }^{111}$, pela postura, no geral, mais restritiva frente ao passado monárquico e ao desempenho de Pedro II; e menos severa em relação aos marcos sugeridos pelos regimes políticos - 1822, 1889, 1930. Ainda, pela (re)leitura do paradigma - "antigo-regime, latifúndio, servidão, escravidão" - agora mais assemelhada à de Joaquim Nabuco, ou seja, projetando-se a categoria escravidão e seu legado à sociedade brasileira ${ }^{112}$. Nessa apropriação, contudo, pode-se notar uma importante diferença: enquanto Nabuco a concebera como "cancro", apenas um empecilho à instalação de uma genuína monarquia parlamentar, a ser superado por uma "revolução pacífica" e regeneradora, retomando Licínio Cardoso, Bomfim e outros críticos republicanos, aqueles historiadores tornaram-na fundamento da sociedade monárquica, cujo desaparecimento arruinara o Império. Dessa forma, nelas, e a partir delas, criou-se um estreito vínculo entre revolução, escravidão e o percurso da Monarquia no Brasil.

Entretanto, as diferentes referências e motivações políticas desses intérpretes ensejariam imagens particularizadas do período monárquico. Assim, Gilberto Freyre ${ }^{113}$ considerou o século XIX - o interregno entre a vinda da corte, a queda da monarquia e os primeiros governos republicanos - um período de "transição da sociedade patriarcal à burguesa" pautado pelo conflito, acomodação e, por fim, declínio do "patriarcado agrário e escravocrático", uma instituição "feudal" inédita engendrada nas "casasgrandes" entre os séculos XVI e XVIII - no "norte açucareiro e na região

110 Sobre as imagens e concepções veiculadas nessas matrizes literárias - romances e relatos de viajantes do século XIX - apreendidas por esses intérpretes ver: NAXARA, Márcia R. Capelari. Cientificismo e sensibilidade romântica. Em busca de um sentido explicativo para o Brasil no século XIX. Brasília: Ed. UnB, 2004.

111 A reverência aos heróis do passado, e ao Império, como condição sine qua non para a feitura da "consciência nacional", teve continuidade no IHGB e na Revista Cultura Política, publicação do Estado Novo. Cf. GUIMARÃES, L. M. P. Da Escola Palatina ao Silogeu. Op. cit., p. 79-133; e GOMES, A. C. História e historiadores. Op. cit., p. 140-157.

112 MARSON, I. A. Politica, história e método em Joaquim Nabuco. Op. cit., p.105-139.

113 Sobre Freyre ver: BASTOS, Elide R. Gilberto Freyre e a formação da sociedade brasileira. Tese (Doutorado). São Paulo: PUC, 1986; D’ANDREA, Moema S. A tradição re(des) coberta. Campinas: Ed. Unicamp,1992; Centenário de Gilberto Freyre. Revista Symposium. Ano 4. Número especial, dez.-2000; Céu \& inferno de Gilberto Freyre. Caderno Mais! Folha de S. Paulo, 15/03/2000. 
cafeeira do sul" - pela iniciativa e trabalho associado dos colonizadores ibéricos e dos cativos negros e índios. Resultado da solicitação comercial europeia, da "plasticidade" do elemento lusitano e da "miscigenação racial", fora ela a grande responsável pelo exemplar "equilíbrio dos antagonismos entre senhores e escravos", garantia de sua solidez e longevidade ${ }^{114}$. Tal declínio deveu-se ao "aburguesamento" da sociedade patriarcal no século XIX - quando os "sobrados" subrepujaram as "casas-grandes" -, incentivado pelo Estado português e, depois o imperial, que desmobilizaram econômica e políticamente o "poder senhorial" ao privilegiar os interesses estrangeiros promovendo os bancos, a urbanização, a industrialização, a imigração e, por fim, a abolição do tráfico e da escravidão ${ }^{115}$.

Freyre reuniu e (re)significou assertivas da bibliografia e fontes disponíveis, especialmente dos relatos dos viajantes ${ }^{116}$ para, inspirado na filosofia dos Agrarians $^{117}$, problematizar a forma como o progresso vinha sendo concebido e implementado na República, e alertar os políticos sobre a contingência de se contemplar o passado na feitura do presente, conforme bem soubera fazer a aristocracia imperial ${ }^{118}$. Nesse sentido, demonstra o quanto o

114 "A casa-grande de engenho que o colonizador começou, ainda no séc. XVI, a levantar no Brasil [...] não foi nenhuma reprodução das casas portuguesas, mas uma expressão nova, correspondendo ao nosso ambiente físico e a uma fase surpreendente do imperialismo português: sua atividade agrária e sedentária nos trópicos; seu patriarcalismo rural e escravocrata [...]. Desde esse momento o português [...] tornou-se luso-brasileiro; o fundador de uma nova ordem econômica e social. [...] A casa-grande, completada pela senzala, representa todo o sistema econômico, social, político de produção (a monocultura latifundiária); de trabalho (a escravidão); de transporte [...] de religião [...] de vida sexual e de família (o patriarcalismo polígamo) [...] de política (o compadrismo) [...]”. FREYRE, Gilberto. Casa-Grande \& Senzala. 12. ed. Brasília: Ed. UnB, 1963, p. 10. (1. ed. 1933).

115 FREYRE, Gilberto. Sobrados e mocambos. Decadência do patriarcado rural e desenvolvimento do urbano. 5. ed. Rio de Janeiro: José Olympio; Brasília: INL, 1977. p. 3-22. (1. ed. 1936).

116 Sobre a valorização das fontes estrangeiras na obra de Freyre, Holanda e Prado Jr. ver: GALVÃO, Cristina G. A escravidão compartilhada: os relatos de viajantes e os intérpretes da sociedade brasileira. Dissertação (Mestrado). Campinas: Unicamp, 2001.

117 Grupo de intelectuais norteamericanos da Universidade de Vanderbilt (Nashvile-Tennessee) organizados após a primeira grande guerra - dos quais Freyre teria se aproximado nos anos 30 -, que refletiram sobre os males da Guerra de Secessão e da sociedade industrial americana, questionando especialmente o abandono da população negra e o utilitarismo. Em contrapartida, "buscavam uma reconciliação entre tradição e progresso, apregoando a preservação dos costumes e cultura do Sul rural como alternativa de civilização, além de apostar nos valores religiosos do humanismo cristão". A autora assinala ainda os liames com movimentos católicos como a Action Française e a Opus Dei. CANCELLI, Elizabeth. Brasil e os outros. Tese (Livre-Docência) - Departamento de História - FFLCH-USP. 2008, p.158-161.

118 "Oliveira Vianna pregava a necessidade para o Brasil de uma legislação, de uma 'arquitetura política', de um novo sistema político em que o legislador [...] 'antes de se mostrar homem de seu tempo se mostrasse de sua raça e de seu meio'. Poderia talvez ter acrescentado: do seu passado [...] Sob a chamada 
"poder senhorial" sediado nos engenhos, e os estadistas que o representaramAraújo Lima, Carneiro Leão, Cotegipe, Paulino, dentre outros - sem descurar da "ordem", haviam sido "conservadores plásticos" e abertos às inovações, partilhando assim "a virtude britânica da contemporização, sendo homens atentos ao futuro - no trópico americano" 119 . A melhor forma de encaminhar o progresso remetia-se ao exemplo da monarquia inglesa, "harmonizando e equilibrando antagonismos entre os homens, as gerações, os credos, as classes, os povos, os sexos, as raças" ${ }^{\prime 20}$, pois o tempo, enquanto fenômeno tríbio, se engendrava como "encontro" de passado e futuro, no presente ${ }^{121}$. Valorizando a obra dos colonizadores, e simpatizando "como Nabuco e Ruy Barbosa" com a opção por uma monarquia "federal, americanizada, separada da Igreja e da grande Propriedade" e "mais identificada com as Forças Armadas e com a gente média do que a monarquia de Pedro II", Freyre questiona a ênfase dada ao programa industrial e imigratório republicano, para ele afinados com os interesses do sul e na contramão de outras expectativas regionais e da vocação nacional, ou seja, a agricultura ${ }^{122}$.

Noutra leitura, referida a categorias analíticas de Max Weber, Buarque de Holanda ${ }^{123}$ concebeu o Império como um período de continuidade, quase plena, da "civilização de raízes rurais", mas "não agrícolas", "semicapitalista", "transplantada" e "adaptada" pelos portugueses aos trópicos, mais assemelhada

Primeira República acentuou-se [...] nos brasileiros da classe dominante a disposição ou o empenho de se parecer mais com os seus contemporâneos dos países mais adiantados do que com seus pais e avós do tempo do Império [...] Mística naturalmente derivada da convicção [...] de sermos um País vergonhosamente atrasado em progresso técnico e científico [...] [para eles] A república nos libertaria de nossos arcaísmos". FREYRE, G. Ordem e progresso. Op. cit., p.51.

119 FREYRE, G. Sobrados emocambos. Op. cit., p. 52-54; Ordem e progresso. Op. cit., p. 56.

120 FREYRE, Gilberto. Ingleses no Brasil: aspectos da influência britânica sobre a vida, a paisagem e a cultura no Brasil. Rio de Janeiro: José Olympio, 1948. p. 24.

121 "O tempo social é sempre um encontro desses três tempos num só, com ora um, ora outro, dentre eles, mais dominante, embora nunca exclusivo". FREYRE, Gilberto. Como e por que sou e não sou sociólogo. Brasília: Ed. da UnB, 1968, p. 31. Em sua perspectiva o Brasil comportava tanto diferenças regionais quanto "vários Brasis" no que dizia respeito ao tempo: no século XIX a maioria da população vivia na "Idade Feudal"; negros e indígenas seriam ainda mais primitivos, enquanto alguns poucos brasileiros, além dos europeus, eram contemporâneos àquele século. FREYRE, Gilberto. Vida social no Brasil nos meados do século XIX. Trad. Waldemar Valente. 2. ed. Rio de Janeiro: Ed. Artenova; Recife: Fundação Joaquim Nabuco, 1977, p. 39. (1. ed. em inglês, 1926); 1. ed. brasileira, 1964.

122 FREYRE, G. Ordem e progresso. Op. cit., p. 160, 179.

123 Sobre Holanda ver: "Sérgio Buarque de Holanda". 3. ${ }^{\circ}$ Colóquio UERJ. Rio de Janeiro: Imago, 1992. MONTEIRO, Pedro Meira; EUGÊNIO, João Kennedy. Sérgio Buarque de Holanda. Perspectivas. Campinas: Ed.Unicamp; Rio de Janeiro: Ed. UERJ, 2008. 
ao modelo da antiguidade clássica ${ }^{124}$ do que das colônias americanas do norte e mesmo da América espanhola ${ }^{125}$. Ela se viabilizara pelo esforço e "plasticidade" cultural e étnica dos lusos, motivados pela "ética de aventura" - audácia, imprevidência, expectativa de recompensa imediata e desprezo pelo trabalho operoso, metódico e disciplinado - princípios que conformaram nossas instituições coloniais: a grande propriedade rural rústica autossuficiente trabalhada por escravos; centros urbanos criados como "simples dependências dela"; um patriciado rural autônomo, com amplo poder sobre a família patriarcal e seus dependentes, sobre outros setores sociais (dentre eles uma burguesia incipiente), e sobre as instituições político-administrativas; e uma mentalidade assentada no "culto da personalidade", carente de qualidades disciplinadoras, racionalizadoras e associativas dada a desmoralização do trabalho e o domínio da "moral das senzalas" ("com sua suavidade dengosa e açucarada") na administração, na economia, nas crenças religiosas ${ }^{126}$.

Essencialmente apoiada na escravidão, essa "herança rural" impediria quase completamente, até a Abolição, em 1888 - "marco divisório de duas épocas" -, experiências políticas revolucionárias, a expansão dos bancos, negócios e cidades e, com eles, o desenvolvimento de uma burguesia urbana independente e empreendedora, como a existente nos países marcados pela "revolução industrial, em particular os anglo-saxões". Seu domínio se exerceu a tal ponto que os progressos materiais ocorridos após a abolição do tráfico (entre 1850-88) - simples desdobramentos das atividades rurais - aconteceram mediante conflitos, tentativas fracassadas, no geral promovidos por "representantes da classe dos antigos senhores", os bacharéis, que atuaram em favor do fim do cativeiro:

124 "O cidadão da antiguidade clássica foi sempre, de início, um homem que consumia os produtos de suas próprias terras, lavradas por seus escravos. Apenas não residia nelas. Em alguns lugares da área do Mediterrâneo, na Sicília, por exemplo - segundo Max Weber - não residiam os lavradores, em hipótese alguma, fora dos muros das cidades, devido à insegurança. [...] No Brasil colonial, entretanto, as terras dedicadas à lavoura eram a morada habitual dos grandes. Só afluíam eles aos centros urbanos a fim de assistirem aos festejos e solenidades". HOLANDA, Sérgio Buarque. Raizes do Brasil. 2. ed. revista e ampliada. Rio de Janeiro: José Olympio, 1948. p. 120-1. (1. ed. 1936).

125 "Trazendo de países distantes nossas formas de vida, nossas instituições e nossa visão do mundo e timbrando em manter tudo isso em ambiente muitas vezes desfavorável e hostil, somos ainda uns desterrados em nossa terra [...] o certo é que todo fruto de nosso trabalho ou de nossa preguiça parece participar fatalmente de um sistema de evolução natural de outro clima e de outra paisagem". Ibid., p.15.

126 Ibid., p. 60-65. 
Na Monarquia eram ainda os fazendeiros escravocratas e eram filhos de fazendeiros, educados nas profissões liberais, quem monopolizava a política, elegendo-se ou fazendo eleger seus candidatos, dominando os parlamentos, os ministérios, em geral todas as posições de mando, e fundando a estabilidade das instituições nesse incontestado domínio. Tão incontestado, em realidade, que muitos representantes da classe dos antigos senhores puderam, com freqüência, dar-se ao luxo de inclinações antitradicionalistas e mesmo empreender alguns dos mais importantes movimentos liberais que já se operaram em todo o curso de nossa história. A eles, de certo modo, também se deve o bom êxito de progressos materiais que tenderiam a arruinar a situação tradicional, minando aos poucos o prestígio de sua classe e o principal esteio em que descansava esse prestígio, ou seja, o trabalho escravo ${ }^{127}$.

Apesar das dificuldades, a monarquia parlamentar - instituição aqui associada ao Poder Moderador - cumpriu "um papel histórico" de lentamente superar as "raízes ibéricas", intervindo especialmente na escravidão. Dessa forma, apenas com a Abolição e a República, iniciarase a "revolução brasileira, a única que rigorosamente temos experimentado em nossa vida nacional, um processo demorado, porém seguro, que vem durando pelo menos há três quartos de século". Embora inconclusa, ela vinha instaurando o predomínio das cidades sobre o mundo rural, da burguesia sobre o "patriciado" decadente, além de viabilizar a emergência das classes médias $^{128}$.

Caio Prado Jr. ${ }^{129}$ faria uma terceira interpretação: nem declínio, nem continuidade, o Império teria sido "o período mais interessante da evolução brasileira", "fase de transformação da estrutura colonial em moderna" e

127 Ibid., p.89-90.

128 "Ainda testemunhamos presentemente, e por certo continuaremos a testemunhar durante largo tempo, as ressonâncias últimas do lento cataclisma, cujo sentido parece ser o do aniquilamento das raízes ibéricas da nossa cultura para a inauguração de um estilo novo, que crismamos talvez ilusoriamente de americano [...] Se a forma de nossa cultura ainda permanece nitidamente ibérica e lusitana, deve atribuirse tal fato sobretudo às insuficiências do 'americanismo', que se resume até agora, em grande parte, numa sorte de exacerbamento de decisões impostas de fora, exteriores à terra.” Ibid., p. 255-56.

129 Sobre Caio Prado Jr ver: MARTINEZ, Paulo Henrique. A dinâmica do pensamento crítico: Caio Prado Jr. (1928-1935). Tese (Doutoramento). São Paulo: FFLCH-USP, 1999; IUMATI, Pedro T. Caio Prado, historiador e editor. Tese (Doutoramento). São Paulo: FFLCH-USP, 2001. "A prova do tempo". Caderno Mais! Folha de S. Paulo, 4/02/2007. 
de formação "da grande burguesia nacional" 130 . Na busca do "sentido" dos eventos constitutivos da história do país, constrói uma "síntese de sua evolução política" inspirada em "interpretação materialista da história" onde demonstra que aquela "estrutura colonial" compusera-se, originalmente, por "grandes propriedades rurais" monocultoras (os latifúndios) trabalhadas por escravos negros, índios e homens livres dela dependentes, pilares de uma sociedade integrada por grandes e poderosos proprietários e uma "população espúria de trabalhadores escravos e semilivres" sediada no campo e em algumas "vilas rurais"131.

O "sentido comercial" inédito desse "grande domínio rural" foi inequívoco, pois ocupou território "descoberto" pela expansão portuguesa e europeia do século XVI ${ }^{132}$ e destinou-se, sobretudo, ao cultivo de produtos agrícolas para o mercado externo, atividades que promoveram, ao longo do tempo, o enriquecimento dos senhores, a ampliação do comércio, dos centros urbanos e a expansão de uma classe de mercadores portugueses. Tal "evolução" da "estrutura colonial" resultaria em mudanças nas relações políticas e administrativas e em conflitos, pois a autonomia desfrutada pela colônia durante os primeiros tempos foi substituída, no século XVIII, pelo "parasitismo" metropolitano - severo controle político e extorsão fiscal - motivos "do rompimento do equilíbrio político do regime colonial" e da luta pela "emancipação"133.

Associando a periodização sugerida por Joaquim Nabuco e Oliveira Lima, Prado Jr. organiza os eventos atinentes à monarquia em dois grandes

130 PRADO Jr., Caio. Roteiro para a historiografia do segundo reinado (1840-1889). In: Evolução política do Brasil e outros estudos. 4.. ed. São Paulo: Brasiliense, 1963. p. 199.

131 PRADO Jr., Caio. Evolução política do Brasil e outros estudos. Op. cit., p. 26-27.

132 "Em suma e no essencial, todos os grandes acontecimentos desta era, que se convencionou com razão chamar dos 'descobrimentos', articulam-se num conjunto que não é senão um capítulo da história do comércio europeu [...] No seu conjunto, e vista no plano mundial e internacional, a colonização dos trópicos toma o aspecto de uma vasta empresa comercial, mais completa do que a antiga feitoria, mas sempre com o mesmo caráter que era destinada a explorar, os recursos naturais de um território virgem em proveito do comércio europeu. É este o verdadeiro sentido da colonização tropical, de que o Brasil é uma das resultantes; e ele explicará os elementos fundamentais, tanto no econômico como no social, da formação e evolução histórica dos trópicos americanos”. PRADO Jr., Caio. Formação do Brasil Contemporâneo. 19. ed. São Paulo: Brasiliense, 1986. p. 22, 31. (1. ed. 1942).

133 "A nossa evolução política segue portanto passo a passo a transformação econômica que se opera a partir de meados do século XVII. [...] O choque dessas forças contrárias [interesses nacionais e lusitanos] assinala a contradição fundamental entre o desenvolvimento do país e o acanhado quadro do regime da colônia. Dele vai resultar a nossa emancipação.” PRADO Jr. Evolução política do Brasil e outros estudos. Op. cit., p. 41. 
momentos. O primeiro, período da "Revolução Burguesa" (1808-1849) - do confronto entre tendências democráticas populares e reacionárias - reúne a transferência da corte, que conferiu "à nossa emancipação política um caráter que a singulariza no conjunto do processo histórico da independência das colônias americanas"; a Independência, o 7 de abril e a Menoridade circunstância das Regências, de reformas na Constituição e debelamento das revoltas e agitações nas províncias. No segundo - denominado "O Império" (1849-1889), "a grande burguesia nacional entra no gozo indisputado do país" 134 usufruindo das realizações impulsionadas pelos capitais liberados na abolição do tráfico de escravos: as estradas de ferro, a urbanização das cidades importantes, a modernização técnica da lavoura.

Porém, o surto progressista foi travado na década de 1870 pelas resistências à abolição da escravidão ${ }^{135}$ e limitações políticas de Pedro II, que, embora não pudesse ser acusado de "abuso do poder pessoal", fizera sempre uma política conservadora:

Por que essa imobilidade do Império? Por que esta incapacidade de se adaptar ao processo evolutivo do país? Já falamos das instituições em que se fundava [o Senado vitalício e o Conselho de Estado] e que lhe emperravam a marcha. Mas, ao lado delas estava o próprio Imperador, escorando-se e escorando também todo o vetusto arcabouço da política retrógrada dos Cotegipes e Itaboraís. Absorvido nas minúcias administrativas e manias literárias que em seu medíocre espírito degeneraram em diletantismo vazio, era D. Pedro o instrumento talhado para realizar essa política: apavorava-o tudo que fosse mudança, temia tudo quanto significasse marcha para a frente. $O$ último decênio do império é de completa decomposição ${ }^{136}$.

134 “.... amaina-se finalmente a agitação dos anos anteriores. Os 'farrapos' depõem armas [...] e em 1849, último reduto da revolução, Pernambuco, entra em fase de tranqüilidade. O Império afinal se estabiliza no seu natural equilíbrio: a monarquia burguesa. Esmagada a revolução, subjugada a onda democrática, $[. .$.$] pode assim a grande burguesia indígena entregar-se ao plácido usufruto de toda a nação.$ Daí por diante as lutas são no seu seio. É dentro dela que vamos encontrar os germes da discórdia, e será a luta destas tendências opostas de grupos burgueses [progressistas e escravistas] que constituirá a história política da segunda metade do século passado". Ibid., p. 81-82.

135 "O eixo principal em torno de que gira esta luta é naturalmente a questão do elemento servil. Depois de 1865 ela quase monopoliza a atenção política do império. Constituía já então o braço escravo o maior obstáculo ao desenvolvimento do país. [...] a favor da escravidão estavam tão-somente os proprietários de escravos e contra, todas as demais forças políticas e sociais do país." Ibid., p. 89.

136 Ibid., p. 93 
O predomínio do conservadorismo no final do Império, e mesmo na República, impediu que a "evolução" econômica e social do país se completasse, nele convivendo lado a lado uma "civilização moderna que se emparelha à dos povos mais desenvolvidos da atualidade e formas antiquadas que sobraram da colônia". Assim permaneciam: "um regime de trabalho neosservil"; a produção centrada em um produto; a falta das "bases de uma economia propriamente nacional"; o insucesso de instituições e práticas políticas e jurídicas "mais compatíveis com a civilização e vida contemporâneas". Na origem desses problemas estavam "grandes obstáculos" antepostos por uma "sociedade caótica e instável"; o vigor da tradição remanescente do passado; o fato de os políticos e legisladores deixarem-se "levar excessivamente pelos exemplos e modelos europeus, onde buscavam de preferência seus conhecimentos, sem tomarem a devida conta da diversidade do Brasil"137.

Associando muitos autores - desde Pereira da Silva, Varnhagen e Oliveira Vianna até Gilberto Freyre, Câmara Cascudo, Alcântara Machado e Caio Prado Jr. -, Nelson Werneck Sodré compôs na década de 1940 uma quarta leitura sobre o Império, período interpretado simultaneamente como continuidade/declínio/evolução e, sobretudo,"desequilíbrio", por constituir "um intervalo na consolidação da ideologia republicana emergente nos movimentos coloniais" que interrompeu "a tradição que não era a coesão, era dispersão"138. Dessa forma, a "solução monárquica" torna-se alternativa "circunstancial" a que foi impelida a sociedade brasileira pelas contingências externas - as invasões napoleônicas, a preponderância inglesa e a decadência de Portugal -; e internas: a inusitada transferência da corte, o livre comércio, a expansão da lavoura de café e as rebeliões populares que intimidaram as "oligarquias" do país.

Apesar da independência não ter tido "nenhum caráter revolucionário" nem alterado de "maneira sensível o quadro social, nem mesmo as relações de produção", o Império, em especial o segundo reinado, distanciou o país de seus vizinhos republicanos e acabou por extinguir "o medievalismo da sociedade brasileira" e práticas "primaciais da nacionalidade", ou seja, "as

137 Ibid., p. 202-206.

138 A “dispersão" geográfica, de interesses e de necessidades dos diferentes núcleos coloniais fundamenta a autonomia política e administrativa, e a relação direta e livre desses núcleos com a metrópole. SODRÉ, Nelson Werneck. Panorama do segundo império. São Paulo: Nacional, 1939. p. 10. 
autarquias rurais" constituídas na expansão capitalista comercial portuguesa e europeia; assentadas na grande propriedade territorial monocultora (o latifúndio), na "família patriarcal", na miscigenação e no "trabalho servil" de negros e índios ${ }^{139}$ - fundamentos, especialmente este último, de poderosa "oligarquia rural/clã patriarcal/patriciado/nobreza/burguesia rural"140.

Adequando-se às novas regras da economia internacional, o Império promoveu a elite proprietária assegurando "ordem e unidade", a expansão da lavoura, do comércio e das cidades, particularmente nas províncias do sul. Também incentivou a "elite letrada", as classes médias (que, pela alforria e miscigenação incorporaram negros e mestiços) e a formação da classe militar, após a Guerra do Paraguai. No entanto, por outro lado, destruiu suportes essenciais da "nobreza/burguesia rural" ao finalizar o tráfico e a escravidão, estimular a vinda de imigrantes, fragmentar a propriedade fundiária e, principalmente, implantar severa centralização política, administrativa, fiscal e econômica, pois "a centralização foi o império". Ao suprimir a escravidão de forma imprevidente - porque arruinou a nobreza rural do norte e do sul e não se preocupou com o preparo do liberto para o mercado de trabalho -, e recusar a "federação", o Império atingiu seus próprios alicerces e comprometeu o "equilíbrio" econômico e político da nação:

O grande erro político imperial foi confundir centralização com unidade [...] Nunca pôde o regime, pelos seus mais distinguidos representantes, conformar-se com a federação [era sinônimo de

139 "É na empresa capitalista da grande exploração [...] que o escravo vai se tornar uma força de primeira ordem, e a escravidão a mais sólida, a mais longa e a mais tormentosa das instituições que atravessam a história brasileira, aquela que mais vivamente lhe afetou os padrões, alterando os seus rumos e viscerando de suas conseqüências todas as fases da existência de um povo em que o problema da raça se misturou logo ao problema econômico fundamental da escravidão" [...]. SODRÉ, Nelson Werneck. Formação da sociedade brasileira. Rio de Janeiro: José Olympio, 1944. p. 87.

140 "O panorama da autarquia rural, da primazia do campo, da elaboração lenta de oligarquias poderosas, da constituição de poderosos clãs, há de dominar o desenvolvimento brasileiro de séculos. Chegará à autonomia, passará pelo império. Só entrará em positivo declínio, sob o regime da centralização monárquica, quando a luta de competição comercial, num país cuja produção permanecerá sempre à mercê de flutuações do mercado externo, herança da colônia, acabará relegando a lavoura [...] a uma posição subalterna, à sombra do que tinha sido". Ibid., p. 100. A associação de autores e concepções do Império, e as mudanças de referências teóricas ressoaram nos termos que nomeiam a sociedade brasileira; na avaliação do perfil da empresa colonizadora; e na interpretação do percurso das "elites/classes" do Império. Sobre a vasta obra de Sodré ver: SILVA, Marcos (Org.). Dicionário crítico Nelson Werneck Sodré. Rio de Janeiro: Ed. UFRJ, 2008. 
rebeldia]. Ora, o segundo império se fizera paladino da unidade, ele se debatera por ela [...] solidificara os laços que prendiam as províncias entre si e todas ao centro. Mentalidade de imediatistas, que não podiam ver as conseqüuências destrutivas duma centralização espantosa num país das condições do Brasil. A luta pela descentralização seria a luta contra o regime ${ }^{141}$.

Todavia, além de "trazer em si os germes da sua dissolução" e de ter-se "divorciado da nação", o "colapso pacífico do império" devia ser creditado também ao "absenteísmo" político de Pedro II:

No panorama imperial Pedro II, em vez de representar as forças em jogo, em vez de agir e agitar-se, amesquinhou-se, fugiu ao seu papel, absteve-se de intervir [...] lia os autores favoritos, aumentava a lista dos pensionados do seu "bolsinho", escrevia aos sábios europeus, traduzia versos [...] Se o regime ia se divorciando do país, ele quase se divorciava do regime ${ }^{142}$.

\title{
Considerações finais
}

\author{
Pode-se considerar que os trabalhos dedicados ao Império nas \\ décadas de 1950, 1960 e 1970, dentro e fora das universidades ${ }^{143}$, no geral, \\ retomaram o patrimônio de argumentos e problemáticas aqui tratados e
}

141 SODRÉ, Nelson Werneck. Panorama do segundo império, p. 279.

142 Em contraponto, Caxias atuou em questões cruciais com equilíbrio e bom senso: "mais do que Pedro II foi o império [...] Apoiado na espada e no seu conhecimento dos homens, foi que o regime procedeu à integração do país". Ibid., p. 133-138.

143 Destacam a Universidade como marco da pesquisa histórica: os já citados José Honório Rodrigues, Pedro Moacyr Campos, Francisco Iglesias, e LAPA, José Roberto do Amaral. Historiografia brasileira contemporânea. (A história em questão). 2. ed. Petrópolis: Vozes, 1981. Balanços dos trabalhos que trataram do tema Independência foram realizados por: Cf. MOTA, Carlos Guilherme (Org.). 1822 : Dimensões. São Paulo: Perspectiva, 1972; OLIVEIRA, Cecília de Salles. A astúcia liberal. Op. cit.; LYRA, M. de Lourdes Viana. História e Historiografia da Independência em questão. Revista do IHGB. Rio de Janeiro, v. 153, n. 377, p. 124-7; 1992; COSTA, Wilma Peres. A Independência na historiografia brasileira. In: JANCSÓ, I. (Org.). Independência. Op. cit., p. 53-118. 
acentuaram a parceria revolução/escravidão para fundamentar análises críticas da monarquia, da república liberal e dos regimes autoritários - o Estado Novo e regime instalado pelo golpe de $1964^{144}$. Nos anos 80, instalou-se significativa inflexão temática ${ }^{145}$ e política decorrente do diálogo entre historiadores brasileiros e norteamericanos dedicados à história da escravidão e do tráfico atlântico de cativos; da divulgação de textos críticos da concepção marxista ortodoxa sobre o movimento operário - Edward Thompson ${ }^{146}$ particularmente; da incorporação de objetos e abordagens sinalizados pela nova história política, pela história social, pela microhistória, pela Nouvelle Histoire e pela História Cultural; e da exploração de fontes inéditas e expansão da pesquisa nos cursos de pós-graduação. A partir daí, o tema escravidão ganhou autonomia ${ }^{147}$ e a revolução, ou adquiriu novos contornos teóricos e interpretativos ${ }^{148}$ ou foi substituída, especialmente a partir dos anos 90, por outras questões políticas - a

144 A exemplo de: HOLANDA, S. B. (Org.). O Brasil monárquico. História Geral da Civilização Brasileira; SODRÉ, Nelson Werneck. História da burguesia brasileira. Rio de Janeiro: Civilização Brasileira, 1964; BEIGUELMAN, Paula. Pequenos estudos de ciência política. 2. ed. São Paulo: Pioneira, 1973; COSTA, E. Viotti da. Da monarquia à república: momentos decisivos. Op. cit.; Da senzala à colonia. São Paulo: Difel, 1966; RODRIGUES, José Honório. Independência: revolução e contra-revolução. Rio de Janeiro: Francisco Alves, 1975. 5 v. A presença do tema "revolução" em teses defendidas na USP na década de 1970 foi analisada por: BURMESTER, Ana Maria. A (des)construção do discurso histórico: a historiografia brasileira dos anos 70. Tese (Titulação). Depto. de História. UFPR, 1992. mimeo. É importante assinalar, contudo, a continuidade de estudos sobre o Império, simpatizantes da monarquia. Cf: SOUZA, Otávio Tarquínio de. História dos fundadores do Império do Brasil. Rio de Janeiro: José Olympio, 1957-58; LYRA, Heitor. História da queda do império. São Paulo: Nacional, 1964. TORRES, João Camillo de Oliveira. Os construtores do Império. Ideais e lutas do partido conservador brasileiro. São Paulo: Nacional, 1968.

145 Ver os seguintes balanços da historiografia recente: MALERBA, Jurandir. (Org.). Independência brasileira: novas dimensões. Rio de Janeiro: Ed. FGV, 2007; e FICO, Carlos; POLITO, Ronaldo. A história do Brasil (1980-1989). Ouro Preto: Ed. UFOP, 1992. 2 v.

146 THOMPSON, Edward P. A formação da classe operária inglesa. Trad. Denise Bottman. Rio de Janeiro: Paz e Terra, 1987, 3 v.; Tradición, revuelta y consciencia de clase. Barcelona: Ed. Critica, 1979.

147 Cf. LARA, Sílvia Hunold. (Org.). Escravidão. Revista Brasileira de História, número especial. V. 8, n. 6, mar.-ago. 1988; SCHWARTZ, Stuart. Escravos, roceiros e rebeldes. Trad. Jussara Simões. Bauru-SP: EDUSC, 2001. Especialmente o cap. "A historiografia recente da escravidão brasileira"; QUEIROZ, Suely Robles. Escravidão negra em debate. In: FREITAS, M. C. Historiografia brasileira em perspectiva. Op. cit., p. 103-118; GORENDER, Jacob. A escravidão reabilitada. S. Paulo: Ática, 1990.

148 Veja-se, por exemplo: CARVALHO, José Murilo de. Teatro de sombras: a política imperial. S. Paulo: Vértice, Ed. Revista dos Tribunais; R. de Janeiro: IUPERJ, 1988; MATTOS, Ilmar R. O tempo saquarema. Op. cit.; MARSON, Izabel A. O império do progresso. Op. cit. 
democracia, o(s) liberalismo(s), as identidades sociais, a sociedade civil, o Estado Nacional, o espaço público e a cultura política ${ }^{149}$.

Entretanto, respeitando-se os "laços permanentes" 150 entre história e política reiterados por tantos teóricos - desde Aléxis de Tocqueville e Karl Marx até Claude Lefort e François Hartog ${ }^{151}$; a relação essencial entre "o novo" (a revolução em seus múltiplos matizes) e a história, enfatizada por Hannah Arendt ${ }^{152}$, além dos depoimentos dos indivíduos que viveram e refletiram sobre o Império, evidencia-se que os estudos sobre o período monárquico não podem prescindir da referência à revolução liberal. Nesse sentido, é possível conceber que essa referência esteja vivenciando, nesse momento, uma forma de "eclipse"153, ou seja, desprestigiada enquanto motivação em virtude da crise do(s) marxismo(s), do desencanto com as experiências republicanas, socialistas e comunistas no século XX, ela tem se ocultado naquelas outras temáticas acima mencionadas, todas elas geneticamente imbricadas no ideário das utopias e movimentos liberais do mundo moderno ${ }^{154}$.

149 Sobre as (re)leituras da revolução e emergência desses outros temas ver: DECCA, Edgar de. A revolução acabou. Revista Brasileira de História (Reforma e revolução). V. 10, n. 20, mar.-ago. 1991; CAPELATO, M. Helena. História Política. Revista Estudos Históricos. Rio de Janeiro, n. 17, 1996, p. 1; D’ALESSIO, Márcia; JANOTTI, Maria de Lourdes. A esfera do político na produção acadêmica dos programas de pós-graduação (1985-1994). Revista Estudos Históricos. Rio de Janeiro, n. 17, 1996.

150 Utilizo a expressão de BORGES, Vavy Pacheco. História e política: laços permanentes. Revista Brasileira de História, n. 23-24. set. 91-ago. 92, p. 7-18.

151 TOCQUEVILLE, Aléxis. O antigo regime e a revolução. Trad. Yvonne Jean. Brasília: Ed. UnB, 1979; MARX, Karl. O Dezoito Brumário de Luis Bonaparte. In: Manuscritos econômicos e filosóficos e outros textos escolhidos. Seleção de textos de José A. Giannotti. Trad. José Carlos Bruni et al. 2. ed. São Paulo: Abril Cultural, 1978; LEFORT, Claude. As formas da História. Trad. Luiz Roberto S. Fortes e Marilena Chauí. São Paulo: Brasiliense, 1979; Pensando o político. Ensaios sobre democracia, revolução e liberdade. Rio de Janeiro: Paz e Terra, 1991; HARTOG, François. O espelho de Heródoto. Ensaio sobre a representação do outro. Belo Horizonte: Ed. UFMG, 1999.

152 ARENDT, Hannah. Da revolução. São Paulo: Ática, 1988; O que é politica? Úrsula Sontheimer (Org.). Trad. Reinaldo Guarany. 5. ed. Rio de Janeiro: Bertrand Brasil, 2004.

153 O termo "eclipse" foi utilizado por François Hartog, escudado em Ricoeur e Barthes, para designar o suposto "desaparecimento" da narrativa no discurso da história-ciência. HARTOG, François. A arte da narrativa histórica. In: BOUTIER, Jean; JULIA, Dominique (Orgs.). Passados recompostos. Campos e canteiros da história. Trad. Marcela Mortara e Anamaria Skinner. Rio de Janeiro: Ed. UFRJ: Ed. FGV, 1998, p. 193-204.

154 Cf. ARENDT, H. Da revolução. Op. cit.; BAYLIN, Bernard. As origens ideológicas da revolução americana. Trad. Cleide Rapucci. Rev. Modesto Florenzano. Bauru-SP: EDUSC, 2003; SKINNER, Qüentin. Liberdade antes do liberalismo. São Paulo: Ed. Unesp/Oxford: Cambridge University Press, 1999; POCOCK, John G. A. Linguagens do ideário político. Sérgio Miceli (Org.). Trad. Fábio Fernandez. São Paulo: Edusp, 2003. 
Por sua vez, ao que tudo indica, as reflexões sobre o tema escravidão parecem continuar a pressupor a expectativa de uma revolução liberal inacabada. Ela permanece, por exemplo, nas explicações que atribuem carências sociais e políticas do país ao passado colonial e imperial, e à associação "ambígua" ou "paradoxal" entre liberalismo e escravidão, motivo da dessemelhança e descompasso histórico entre o Império, de um lado, e a Europa e os Estados Unidos, de outro ${ }^{155}$. Nesse sentido, vale a pena observar o vigor e plasticidade da tradição argumentativa que abordamos nesse artigo e o quanto ela continua a inviabilizar revisões efetivas na interpretação do Império - já propostas, diga-se de passagem, por Maria Sylvia Carvalho Franco ${ }^{156}$ na década de 1960 -, assim como o direito à "maioridade" aos homens e mulheres que vivenciaram o período monárquico no Brasil.

155 Conforme demonstra a chamada de artigos da Revista Eletrônica Cadernos de História, ano 4, n. 1, dedicado ao tema Escravidão, trabalho e tráfico atlântico: "A Pesquisa Nacional por amostra de domicílios (PNAD) evidencia uma verdade com a qual a sociedade brasileira há séculos se depara: a diferença de renda de um branco em relação ao afro-descendente: 2,06 mais. Tal fato tem origem no processo histórico de formação da sociedade ocidental moderna, que se construiu a partir de um paradoxo. A mesma sociedade que inventou a liberdade foi a que construiu os piores sistemas de exploração escravista. No Brasil, nosso passado colonial e imperial se formou dentro dessa dimensão conflitiva e ambígua. [...] Por isso, estudar Escravidão, trabalho e tráfico atlântico é ir às origens da nossa formação social. É buscar respostas para como noções de poder, liberdade, cidadania e direitos políticos se conformaram ao longo de nossa história." (mensagem divulgada em 13/11/2008)

156 FRANCO, Maria Sylvia Carvalho. Homens livres na ordem escravocrata. São Paulo: IEB, 1964. A autora demonstra os fundamentos capitalistas e liberais vigentes na sociedade imperial. Sobre os estreitos vínculos entre liberalismo e escravidão até o séc. XIX, da mesma autora, "As idéias estão no lugar". Cadernos Debate, v. 1, p. 59-64. São Paulo: Brasiliense, 1976; All the world was America. John Locke, liberalismo e propriedade como um conceito antropológico. Revista USP, v.17, p. 30-53, marçomaio, 1993. As ideias de Franco foram acolhidas por alguns historiadores: Cecília Salles Oliveira, Stella Bresciani, Izabel Marson e os integrantes do Núcleo História e Linguagens Políticas e seus orientandos, grupo de pesquisa CNPq coordenado por Stella Bresciani e Izabel Andrade Marson. 